\title{
Single EV analysis (sEVA) of mutated proteins allows detection of stage 1 pancreatic cancer
}

Scott Ferguson'1, Katherine S. Yang1, Piotr Zelga 2, Andrew S. Liss 2, Jonathan Carlson ${ }^{1}$, Carlos Fernandez del Castillo1,2, Ralph Weissleder 1,3,*

${ }^{1}$ Center for Systems Biology, Massachusetts General Hospital, 185 Cambridge St, CPZN 5206, Boston, MA 02114,

2 Department of Surgery, Massachusetts General Hospital, 32 Fruit St, Boston, MA 02114,

3 Department of Systems Biology, Harvard Medical School, 200 Longwood Ave, Boston, MA 02115

${ }^{*}$ R. Weissleder, MD, PhD

Center for Systems Biology Massachusetts General Hospital 185 Cambridge St, CPZN 5206

Boston, MA, 02114

617-726-8226

rweissleder@mgh.harvard.edu

Short title: Single vesicle analysis for early cancer detection

Keywords: PDAC, early detection, exosome, extracellular vesicle 
medRxiv preprint doi: https://doi.org/10.1101/2021.09.26.21263660; this version posted September 27, 2021. The copyright holder for this preprint (which was not certified by peer review) is the author/funder, who has granted medRxiv a license to display the preprint in perpetuity. All rights reserved. No reuse allowed without permission.

\begin{abstract}
Tumor cell derived extracellular vesicles (EV) are being explored as circulating biomarkers for cancer detection. Up to now however, clinical results have been mixed for a number of reasons including the predominant use of bulk measurements, the inability to differentiate tumor from host cell derived vesicles, the general absence of uniquely identifying biomarkers and the unknown frequency of stochastically distributed biomarkers into single circulating vesicles. We hypothesized that a single EV analysis (sEVA) technique could potentially improve diagnostic accuracy necessary to detect early cancers but the actual biomarker frequency and practical detection limits are currently unknown. Using pancreatic cancer, we carefully analyzed the composition of putative cancer markers in 11 established and new patient derived models. In parental PDAC cells positive for KRASmut and/or P53mut proteins only $\sim 40 \%$ of EVs were also positive (range: $30-64 \%$ ). This rate of positivity increased to $57 \%$ when additional PDAC biomarkers were considered (MUC1, EGFR, $\alpha$ FG-P4OH) in cell lines. In a blinded study involving 16 patients with surgically proven stage 1 PDAC, KRASmut and P53mut protein was detectable at much lower levels, generally in $<0.1 \%$ of vesicles. With the analytical capabilities of sEVA however, 15 of the 16 patients with stage 1 PDAC expressed low levels of biomarker positive EV. Using a modeling approach, we estimate that the current PDAC detection limit is at $\sim 0.1 \mathrm{~cm}^{3}$ tumor volume, below clinical imaging capabilities. These findings establish the potential for single-EV analysis for early cancer detection.
\end{abstract}

\title{
Introduction
}

Pancreatic ductal adenocarcinoma (PDAC) currently represents the third leading cause of cancer death in the United States and it is expected to become the second leading cause by $2030(1)$. In 2021, 60,430 Americans are expected to develop pancreatic cancer and an estimated 48,220 Americans will die from the disease (https:// seer.cancer.gov/statfacts/html/pancreas.html). The only way to cure pancreatic cancer is to surgically resect it when it is still localized. Under the current therapeutic paradigm, only $20 \%$ of patients will present with surgically resectable disease, while $40 \%$ will present with localized but surgically unresectable disease and $40 \%$ will present with metastatic disease. Despite state-of-the-art CT, MRI, and endoscopic ultrasound for patients with "localized disease by imaging" and who undergo surgery, the rate of pathologically positive margins is $40-70 \%$ and the rate of pathologically positive peripancreatic nodal disease is $60-80 \%$. If we are to cure more patients with pancreatic cancer, new diagnostic tools are necessary to identify patients with preclinical and truly localized disease and to explore novel therapeutic approaches to allow for more R0/N0 resections.

High resolution, contrast enhanced CT and MRI imaging are routinely obtained but their sensitivity in detecting minimal disease is often limited especially in the neoadjuvant(2) and postoperative settings. Technological advances continue to rapidly improve the capacity to detect circulating_biomarkers in blood samples(3, 4). Such "liquid biopsy" markers include mutated or methylated cell-free DNA (cfDNA)(5-8), tumor-associated extracellular vesicles $(\mathrm{EV})(9)$, circulating tumor cells (CTC)(10), and metabolic 
medRxiv preprint doi: https://doi.org/10.1101/2021.09.26.21263660; this version posted September 27, 2021. The copyright holder for this preprint (which was not certified by peer review) is the author/funder, who has granted medRxiv a license to display the preprint in perpetuity. All rights reserved. No reuse allowed without permission.

parameters (e.g. onset of diabetes, muscle wasting)(11). Although EV, cfDNA and metabolism markers have already shown promise for PDAC diagnostics, their current detection sensitivities require further improvements to be clinically useful. Especially in early disease, the lower diagnostic accuracy is likely due to the large stromal component of PDAC, coexistence with focal areas of pancreatitis indistinguishable from tumor free pancreatitis, and the low quantity of circulating biomarkers at early stages(7).

We and others have developed a number of methods to analyze $E V(12-15)$. Many of the earlier techniques relied on bulk measurements requiring $10^{2}-10^{6} \mathrm{EV}$ for a single measurement while single EV methods (single EV analysis with multifluorescence, single-particle interferometric reflectance imaging with fluorescence, nanoparticle tracking analysis, microfluidic resistive pulse sensing, nanoflow cytometry) are being actively developed, they measure different parameters (often size rather than molecular biomarkers)(16, 17). Irrespective of the specific physical measurement, the next question is which molecular biomarker to assay. While research is still ongoing, it has also become apparent that many of the described biomarkers have failed in larger clinical validation cohorts(18-20). One of the key questions that has thus emerged is whether this failure is due to the choice of a given molecular biomarker, the extreme heterogeneity of PDAC, or the inability to accurately detect very small numbers of biomarker positive EV in a population of normal EV.

We argue that one way to address the current question is to perform single EV analysis because the identification of a small number of tumor-originating $\mathrm{EV}$ (such as those found in microscopic cancers) in a background of host EV may be impossible by bulk methods. We furthermore hypothesized that mutated oncoproteins (e.g. KRASmut) or tumor suppressor genes (e.g. P53mut) can potentially be detected in single EV, while the same mutations occurring in cancer cells are causal in increased tumoral EV shedding(21-24). The choice of detecting these mutated proteins is also driven by their early appearance in the $\operatorname{PDAC}$ development cascade $(25,26)$. Finally we reasoned that detection efficiency could be improved by multiplexed measurements of several biomarkers. Based on these paradigms, we have developed and validated a robust single EV analytical technique (sEVA) that allows multiplexed protein measurements in individual EV. We apply the sEVA technique to unanswered questions such as i) what is the inherent heterogeneity of putative cancer cell associated proteins in EV, ii) what is the frequency of mutant onco/tumor suppressor proteins in single EV and iii) what are the expression levels of two or more cancer-associated proteins on individual EV? The option of "covering" more tEV by non-overlapping markers or obtaining "highly specific" EV identification like KRASG12D and P53mut presents as a solid option to improve clinical PDAC diagnostics.

\section{Results \\ sEVA is a robust analytical tool}

It is increasingly being recognized that molecular analysis of EV populations will require single vesicle analysis. Compared to bulk methods, single vesicle analysis allows several additional avenues of hypothesis testing such as i) co-localization of distinct 
medRxiv preprint doi: https://doi.org/10.1101/2021.09.26.21263660; this version posted September 27, 2021. The copyright holder for this preprint (which was not certified by peer review) is the author/funder, who has granted medRxiv a license to display the preprint in perpetuity. All rights reserved. No reuse allowed without permission.

molecular markers on the same vesicle, ii) frequency distribution of markers across the population, and iii) with principal component or tSNE analysis, description of discrete EV sub-populations.

In an effort to develop a clinically useful single EV analysis tool we considered multiple pre-requisites: i) the need to unambiguously define an entire EV population by a universal labeling approach since not all molecular markers are present in all EV, ii) antibodies with very high affinity and low non-specific binding, and iii) the need to maximally reduce background signal by stringent purification. To address the first prerequisite, a number of general labeling approaches were tested but many ultimately proved unsuitable for total-EV identification. Lipid-insertion approaches (e.g. Dil, DiO labeling), while able to generate extremely bright $\mathrm{EV}$, have also been shown to assemble into micellular lipid-dye aggregates that cannot be readily distinguished or purified from bona-fide EV. Other approaches such as wheat germ agglutinin, phosphatidylserine binding moieties, or specific protein-labeling approaches such as CD63 ignore that none of these molecules are present on $100 \%$ of EVs, leaving open the possibility that EVs harboring informative markers are not considered(27). We thus optimized a labeling approach using fluorochrome-polyethylene glycol-2,3,5,6tetrafluorophenyl esters ("TFP") to fluorescently label free amines of EV-surface proteins (Fig. 1A, S1), incorporating a long PEG12 linker to optimize labeling efficiency, water solubility, and reduce nonspecific EV binding/aggregation.

Having a bright, stable, and full-coverage pan-EV-labeling strategy is also important because it i) allows calculation of the fraction of biomarker-positive EV (and thus set thresholds) and ii) it can be used to identify staining artifacts in non-TFP-labeled objects. The latter is due to the fact that despite considerable methodological improvements, off-target, (i.e. non-TFP localized) antibody signals, although rare, were present at similar frequencies between positive and negative controls. The major methodological improvements developed during the optimization of the sEVA protocol to reduce the incidence of non-specific antibody signal included, i) using only very pure $E V$ samples from size-exclusion chromatography, ii) utilizing a low antibody concentration $(13 \mathrm{nM})$, with high blocking buffer concentration, and in the most considerable improvement, iii) performing an additional column purification to separate antibodystained EV from free fluorescent antibodies which are retained on the column (Fig. 1B, S1). The in-solution sEVA staining strategy was superior to a previously developed single EV technique that required EV capture to glass slides prior to staining(17). Onslide staining requires strong $\mathrm{EV}$ attachment (such as streptavidin, biotin-capture) which introduces biotinylation manipulation of EV and may bias EV capture while also requiring involved chemical manipulations to coat glass slides with streptavidin/ neutravidin. In our hands these manipulations resulted in non-homogenous background signal and introduction of artifacts that could be hard to distinguish from EV events. Strong capture is required for on-slide staining to allow for washing, however, we found that no washing conditions tested were harsh enough for total removal of background fluorescent antibody signal without also stripping EV off the glass. This of course is undesirable when rare EV are being evaluated. Staining in-solution and then cleaning on column allowed us to attach EV on high optical-purity commercial glass slides coated 
medRxiv preprint doi: https://doi.org/10.1101/2021.09.26.21263660; this version posted September 27, 2021. The copyright holder for this preprint (which was not certified by peer review) is the author/funder, who has granted medRxiv a license to display the preprint in perpetuity. All rights reserved. No reuse allowed without permission.

with a hydrophobic surface (Fig. 1C, S1). EV can be adhered by hydrophobic interactions within 30 minutes and since no additional washing is required, they show minimal mobility and deposited EV can be found in the same location over several days.

A considerable number of putative biomarkers have been proposed for the detection of PDAC including MUC1, MUC2, MUC4, MUC5AC, MUC6, DAS-1, PSCA, TSP-1, TSP-2, PLEC1, S100A4, STMN1, ZEB1, HOOK1, PTPN6, FBN1, CD73, CLDN18, TIMP1, EphA2, CYFRA21-1, LRG1, MSLN, HER2, GRP94, among others(9, 20, 28-40). We investigated mutated onco/tumor suppressor proteins in EV including KRASmut and P53mut $(26,29)$. We were interested in detecting both specific mutations (e.g. KRASG12D vs KRASG12V) and also in detecting all vesicles that harbored any mutated onco/tumor suppressor protein. For this reason, we labeled/detected different specific KRASmut antibodies and a pan-P53mut antibody with the same fluorochrome to allow colocalization with other proteins (Fig. 2). With respect to KRASmut we used antibodies with specificity for G12D and G12V mutations but this paradigm could be expanded to other mutations (KRASG12C, KRAS ${ }^{\mathrm{G} 12 \mathrm{R}}$ ). We also expanded the EV biomarkers to other entities that had shown promise in independent prior studies. These included EGFR(9, 40), MUC1(9), and a prolyl 4-hydroxylated alpha-fibrinogen $(\alpha \mathrm{FG}-\mathrm{P} 4 \mathrm{OH})(41)$.

EVs were then imaged by high-resolution microscopy and analyzed in ImageJ (Fig. 1D, S1). The computational pipeline is summarized in Fig. S3. Briefly, images were confirmed to be free of large artifacts or background abnormalities and found to contain sufficient TFP-labeled EV per field of view (>500). Measurements of the marker signal intensities within TFP-ROls from background subtracted images were imported to GraphPad Prism 8 and a positive threshold was determined by maximum likelihood ratio of the receiver operator characteristic (ROC) curve analysis between positive (cell lines / late clinical) and negative (cell lines / healthy control) samples.

Utilizing a 2-pixel Gaussian blur, EVs labeled with AF488-TFP (green) could be readily observed over the negligible background (Figs. 1, 2) with a signal to-noise ratio $>20$. In the Texas Red acquisition channel we detected EVs positive for either KRASG12D, KRASG12V or P53mut. In the Cy5.5 channel we detected EVs positive for either EGFR over expression, MUC1, or $\alpha \mathrm{FG}-\mathrm{P} 4 \mathrm{OH}$ (Table 3). Care was taken to utilize EV concentrations such that once adhered to the glass slide their spatial separation would minimize the statistical co-incidence of these signals.

EV derived from PDAC cell lines show heterogenous biomarker expression Armed with a robust and practical method for identifying all EV via fluorophore-TFP labeling and characterization via fluorescently-labeled antibodies we next sought to characterize EV of well established PDAC models. A key question was: If a parental PDAC cell ubiquitously expresses a defining cancer biomarker, what is the frequency at which the same biomarker can be identified in the entire EV population produced by the cell line? One would intuitively think that the ratio is $1: 1$, but we had previously observed that this was not always the case, hence a reason for more in-depth analysis. 
medRxiv preprint doi: https://doi.org/10.1101/2021.09.26.21263660; this version posted September 27, 2021. The copyright holder for this preprint (which was not certified by peer review) is the author/funder, who has granted medRxiv a license to display the preprint in perpetuity. All rights reserved. No reuse allowed without permission.

Starting with the AsPC-1 cell line, we found that essentially all parental cells stained positive for KRASmut or P53mut (42). With respect to harvested EV, only $3 \%$ were positive for KRAS ${ }^{12 D}$ or P53mut alone and another 38\% were double positive for the onco/tumor suppressor proteins and MUC1, EGFR or $\alpha$ FG-P4OH. In summary, $48 \%$ of EV were negative for any of the markers. As shown in Fig. 2 there was clear separation of EV signals. Similar data were observed across three other pancreatic cancer cell lines, although the biomarker expression ranged considerably. MIA-PaCa-2 demonstrated the lowest percent coverage with the combinatorial marker panels of any of the tested cell lines, with $52 \%$ of the analyzed MIA-PaCa-2 EV being negative for any of the six markers (Fig. 3B). This may not be entirely surprising as MIA-PaCa-2 is a KRASG12C cell line (G12C specific analysis was not included in our testing panel given the lack of reliable antibodies). PANC-1 showed the highest marker coverage, with $75.7 \%$ of their EVs being positive for at least one of the tested markers (Fig. 3B). With these marker sets we observed most EV were dual positive in both channels meaning they had at least one of KRASG12D/G12V or P53mut and at least one of EGFR, MUC1, or $\alpha \mathrm{FG}-\mathrm{P} 4 \mathrm{OH}$. The biomarker expression levels were similar over time when $\mathrm{EV}$ were re-tested, i.e. similar fingerprints were observed.

We next characterized 7 PDX PDAC patient derived cell lines $(609,950,1275,1309$, 1319,1326 , and 1473) that were originally developed at $\mathrm{MGH}(43)$. These cell lines were characterized by KRASmut EV analysis(KRASG12D: 609, 1309, 1319, 1326; KRASG12V: 950, 1275, 1473), P53mut (609, 950, 1275, 1309, 1319, and 1326), MUC1 (609, 950, $1309,1319)$ or EGFR over-expression $(609,1309,1319,1473)$. Similar to the original manuscript(44) no pancreatic cell lines were positive for the specific prolyl-4 hydroxylated form of $\alpha F G$ detected by this antibody, as it is thought this is a posttranslational modification that occurs within inflammatory sites of the tumor microenvironment after EV secretion. Table 1 summarizes the background information of these cells while Table 2 provides a summary of biomarker presence in EV. Biomarker positive EV were detected in all cell lines positive for a given marker including KRASmut and P53mut. Similarly as in the ATCC panel, we found heterogeneity of expression. For example, in the KRASG12V expressing cell line 1473, where it is estimated that each cell contains hundreds of thousands of KRASG12V proteins(45), 37\% of EVs still did not show expression of the mutant protein. This figure was considerably lower in the other PDX cell lines (Fig 3B).

EV Biomarkers can fluctuate in PDAC clonal populations

To further investigate EV biomarker heterogeneity we performed clonal expansion experiments. In these experiments we isolated single parental PDAC cells and grew them into individual clones from which EV where then harvested and analyzed (Fig. 4A). For PANC-1 (KRASG12D/MUC1 positive), single cell derived clones shed EV that were relatively representative of the parent cell line. Specifically, three tested clones retained high MUC1 expression and similar percentages of KRASG12D positive EV (Fig. 4B,C). In contradistinction, there was considerable heterogeneity in clonal expression with the KRASG12D/P53mut AsPC-1 cell line. Specifically, there was a 5-fold increase in KRASG12D EV for clone 5 likely representative of a heterogenous baseline population. This explanation is further suggested by the fact that there is a $\sim 16$-fold range in 
medRxiv preprint doi: https://doi.org/10.1101/2021.09.26.21263660; this version posted September 27, 2021. The copyright holder for this preprint (which was not certified by peer review) is the author/funder, who has granted medRxiv a license to display the preprint in perpetuity. All rights reserved. No reuse allowed without permission.

KRASG12D signal intensity among parental AsPC-1 cells. Interestingly, the AsPC-1 clones also showed induction of MUC1, with one clone exhibiting MUC1 positivity on $\sim 20 \%$ of its EVs. Strong MUC1 induction has been previously shown for AsPC-1 and some labs report AsPC-1 as a MUC1+ cell line $(46,47)$. These data reinforce the idea that cell line heterogeneity, like tumor heterogeneity, can fluctuate temporally as selection pressures exert themself and that this heterogeneity is reflected in EV. A takeaway from these findings is that single EV analysis is essential to capture low percentages of biomarker positive EV, particularly when measurements are made in plasma and where non-malignant EV abound.

sEVA plasma sample analysis correlates with tumor mutational status Being able to (co-)detect mutant onco/tumor suppressor proteins and other biomarkers in single EV, we next extended sEVA to clinical samples. Plasma, unlike cell culture media, is a more complex mixture of potentially contaminating or confounding matrices, such as particles released upon platelet vesiculation(48), other lipid particles such as HDL and LDL(49), as well as chemical anticoagulants such as EDTA, citrate, or heparin. Using a standardized input concentration of EV, all clinical samples were thresholded to obtain similar TFP-EV counts.

We initially tested the ability of sEVA to identify KRASG12D in a clinical plasma sample from a KRASG12D positive late stage pancreatic cancer patient (Fig. 5). Analyzing a field of view containing 1,618 EV (zoomed Fig. 5A) demonstrated $1.24 \%$ of all EV in circulation were indeed positive for KRAS ${ }^{12 D}$ but the frequency was much lower than observed in cell culture, presumably due to dilution effects. The KRASG12D signal was almost exclusively located on TFP-EVs rather than in secreted form (Fig. 5B). Interestingly, when the same sample was processed by bulk EV analysis, KRASmut became non-detectable against the background of $>99 \%$ KRASmut-negative $E V$. To further validate sEVA in advanced PDAC, we processed additional samples $(n=2$ stage $\mathrm{Ilb}$ and $\mathrm{n}=2$ stage IV). We found the KRASG12D and P53mut marker panel fully separated these four samples from healthy control samples $(n=5)$ and had, on average, greater than 5-fold increased percentage of EV staining positive for the marker panel consisting of MUC1, EGFR, and $\alpha$ FG-P4OH (Fig. 5C). To establish the correlation between the EV onco/tumor suppressor protein analysis and NGS of surgical samples, we analyzed 24 samples where matching information was available (i.e. KRASG12D $n=13$; KRAS wild type $n=8$; P53Mut $n=8$; P53 wild type $n=15)$. KRAS ${ }^{\text {G12D }}$ could be detected in this cohort with $100 \%$ specificity and sensitivity $(p=0.0002)$ and $P 53$ mut was detected at $100 \%$ specificity and $87.5 \%$ sensitivity (Fig. 5 C).

\section{sEVA of plasma samples enables early cancer detection}

We next expanded the measurements to plasma samples from stage 1 pancreatic cancer patients $(n=16)$, although this is a rare clinical scenario as most PDAC will present at a later stage. Nevertheless, early PDAC detection has high clinical value in high-risk groups(50). We defined the threshold for EV staining as "positive" when a given biomarker stained $>2 x$ above an isotype control labeled antibody. Plasma samples from healthy controls contained very low levels of biomarker "positive" EV, although the number was not zero. Fewer than $0.03 \%$ of EV stained weakly positive for 
medRxiv preprint doi: https://doi.org/10.1101/2021.09.26.21263660; this version posted September 27, 2021. The copyright holder for this preprint (which was not certified by peer review) is the author/funder, who has granted medRxiv a license to display the preprint in perpetuity. All rights reserved. No reuse allowed without permission.

KRASmut or P53mut, and fewer than $1 \%$ stained weakly for EGFR, MUC1, or $\alpha$ FG-P4OH (Fig. 6A).

When analyzing the stage 1 PDAC plasma samples we show that 15 of the $16 \mathrm{EV}$ samples were positive for KRASmut and/or P53mut. All 5 samples with known KRAS mutation were positively identified as such and another 5 samples with known P53 mutation were all positively identified as such. Only 1 of the 16 samples had dually positive EV staining for KRASmut and P53mut. For 9 samples the ground truth mutational status was not known, but 5 of these samples (56\%) had EV positive for P53mut and 7 samples (78\%) had EV positive for KRASG12D in line with the expected rate of these mutations in pancreatic cancer (8). Including EV analysis of EGFR, MUC1, and $\alpha F G$ $\mathrm{P} 4 \mathrm{OH}$ further improved the confidence of a correct diagnosis but by itself was less sensitive than oncoprotein/tumor suppressor protein mutational analysis.

\section{Modeling PDAC cancer detection thresholds}

The ability to identify early forms of PDAC shows the clinical potential of sEVA. To address how early the current assay might be expected to detect pancreatic cancers, a modeling approach was necessary. We thus developed a framework model for tumorEV shedding and distribution/elimination kinetics that was able to connect a tumor volume to expected tumor-EV concentrations in circulation (Fig. 7A). Two PDAC mouse models, $\operatorname{KIC}(51,52)$ and $\operatorname{KPC}(51,53)$, were included in the development of the model. Additional information used to inform our model simulations included the EV shed rates observed from the patient derived cell lines as well as the distribution of marker positive EV observed for cancer cell lines.

The ability to detect tumor derived EV (tEV) in circulation is a combination of how many EV are being shed by a tumor as well as the percentage of those EV positive for a given marker. Using the observed distributions in EV shed rate and EV marker coverage, 100 individuals were simulated. Inter-individual variability around other parameters, such as EV distribution/elimination kinetics were assumed constant across the population. Additionally, the distribution simulated for marker coverage left open the very real possibility that some tumors are expected to be completely negative for any of the given markers, here 8 patients were simulated to be marker negative. Of all the model parameters, EV-shed rate showed the greatest variability with a 100-fold difference between the highest and lowest shed rate tumors and thus is likely to represent the largest source of variability in detectable tumor-sizes across a population.

Using the modeling approach, we estimate that $\sim 92 \%$ of patients with a PDAC at a size of $\sim 1 \mathrm{~cm}^{3}(\sim 2 \times 2 \times 2 \mathrm{~mm})$ will be detectable by sEVA. We also estimate that $68 \%$ of patients are likely to be diagnosable with pancreatic cancer at a tumor size of $0.1 \mathrm{~cm}^{3}$ with a specificity of at least $\sim 80 \%$. If in the future, a panel of markers could be assembled to cover $\sim 100 \%$ of all tumor originating $\mathrm{tEV}$, the detection limit of PDAC could be as low as $\sim 0.03 \mathrm{~cm}^{3}$ with similar specificity. 
medRxiv preprint doi: https://doi.org/10.1101/2021.09.26.21263660; this version posted September 27, 2021. The copyright holder for this preprint (which was not certified by peer review) is the author/funder, who has granted medRxiv a license to display the preprint in perpetuity. All rights reserved. No reuse allowed without permission.

\section{Discussion}

Cancer cells release large quantities of EV, a finding that has prompted an exponential growth of this biomarker field. EVs are a heterogeneous group of vesicles varying in size, composition, intracellular biogenesis and cell of origin(54). EV subpopulations are often divided into two groups: vesicles that bud directly from the plasma membrane (microvesicles) and vesicles that originate in endosomal compartments and are secreted by exocytosis (exosomes). Since exosomes and microvesicles partially overlap in size and composition we use the general term 'EV' when the specific cellular origin of the vesicle is unknown(55). A second useful classification is with respect to the compartment of origin(56): those derived directly form tumor cells (tEV) and those derived from host cells (hEV) which likely play different physiological roles.

Tumor cell derived EV can be useful diagnostic biomarkers but also have therapeutic implications. $\mathrm{tEV}$ have been shown to modulate stromal crosstalk, cause immune evasion(57), prime metastatic sites, and lead to drug resistance among others. To take full advantage of $\mathrm{tEV}$, there is thus a need to better understand their kinetics during tumor development and therapy. Furthermore, there is a clear need to decipher why and how EV biogenesis ramps up in cancer cells, and what the specific avenues are for interventions(58). Here, we provide a much more granular insight into the composition and make-up of tEV in PDAC cell lines and in human plasma samples. Contrary to the common belief, we show at the single EV level that specific protein markers are generally low (e.g. 20-30\% of EV are positive for EGFR whereas all parental cells are positive), heterogenous and uncommonly multiplexed unlike in parental cells. We furthermore show that tEV carry mutated onco/tumor suppressor proteins and that these events can be detected by sEVA in plasma.

\section{Mutated proteins in tumor cell derived EV}

KRAS mutation and/or hyperactivation can be found in virtually all PDAC(26). KRAS and other RAS proteins seem to be associated with increased tEV biogenesis. A recent study showed a role for Rab13 in sEV secretion from colorectal cancer cells expressing mutant KRAS (21). Mutant RAS has also been shown to upregulate proteins involved in budding and vesicle exocytosis(59). Downstream targets of RAS have also been shown to control EV secretion from mammary tumor cells(60). We show that some KRAS mutations common in PDAC can indeed be identified in circulating EV using single EV analytics. While $\sim 40 \%$ of cell culture derived EV are positive for KRASmut in mutant cell lines (Fig. 3), the overall presence of KRASmut protein in patient derived samples is much lower. This percentage in plasma is $<0.1 \%$ of $\mathrm{EV}$ in early stage cancers and $\sim 1 \%$ in late stage PDAC (Figs. 5, 6). We assume that this is due to the heterogenous makeup of PDAC, the fact that many EV are shed by non-tumor cells and the stochastic process of internalizing proteins into EV from parental cells. Irrespective of the precise reason, the low numbers indicate that single EV analysis such as sEVA developed here, is essential in early cancer diagnostics. It is much less likely that bulk EV analytical methods will be able to detect scant mutated proteins. Apart from a biomarker for early detection, we posit that EV KRAS analysis should also be useful in future clinical trials of patients receiving KRASG12C/KRASG12D inhibitors. 
medRxiv preprint doi: https://doi.org/10.1101/2021.09.26.21263660; this version posted September 27, 2021. The copyright holder for this preprint (which was not certified by peer review) is the author/funder, who has granted medRxiv a license to display the preprint in perpetuity. All rights reserved. No reuse allowed without permission.

The tumor suppressor P53, is one of the most frequently mutated genes in human cancer and has been been linked to EV release. Direct activation of P53(61) or certain $\mathrm{P} 53$ target genes have been implicated in $\mathrm{tEV}$ secretion $(62,63)$. We show that P53mut is detectable in single EV and that multiplexed analysis can enhance the diagnostic accuracy of PDAC detection. Similar to KRAS, the P53 pathway is also subject to therapeutic development, providing a rationale for tEV monitoring.

There are a number of other mutated proteins in PDAC such as the oncogene GNAS or tumor suppressor genes CDKN2A and SMAD4(8, 64). KRAS and GNAS are near universal features of PDAC and PanIN but may also be present in low-grade precancerous lesions with little risk of malignant transformation. Additional driver genes may have potential utility in early detection of PDAC including RNF43, KLF4, PTEN, PIK3CA, and VHL(8). All of these could potentially be targeted although reliable antibodies that detect all mutations are still awaiting development.

Multiplexing

It is theoretically possible to increase diagnostic specificity by assaying for and codetecting multiple markers in EV. A number of multiplexing technologies have been developed relying mostly on spectral fluorescence, image cycling, immunosequencing (65) and potentially others(66). Irrespective of the approach, vesicular real estate is somewhat limited. An EV has a $10^{6}$ smaller volume compared to an entire cell. Protein packaging into or onto vesicles can thus be limited, while nuclear proteins are essentially absent in all vesicles. We believe that multiple marker analysis and multiplexing will still have particular value in two different scenarios. If mutated proteins are indeed co-detected in the same vesicle, it can be assumed that this is virtually indicative of malignancy. Second, if different EV with different mutated proteins coexist in a population, it raises the certainty by which the EV population arose from a heterogenous cancer. In our cohort of 16 surgically proven stage 1 PDAC cases we found dual KRASmut/P53mut and PDACEV (EGFR, MUC1, $\alpha$ FG-P4OH) positive EV in 12/16 cases (75\%; Fig. 6).

\section{Current challenges}

In this work we have overcome a number of technical challenges while a few others still remain. We hope that future research can address these through further methodological advances. The quality of antibodies is essential in detecting rare and scant proteins. While amplification strategies can help, they also introduce potential errors in measurements. Furthermore, counting vesicular fluorescence events as "positive" requires setting a threshold. Such a threshold can be different for different antibodies and fluorochromes. Irrespective of the approach, it is essential to analyze positive and negative control samples for each measurement. Another area for improvement is to optimize the small volume measurements without losing vesicles during wash and purification steps. Microfluidic approaches could help but they will need to be incorporated into glass devices (not PDMA) to optimize the optical detection. Moving reagents and fluid through such devices without dislodging EV from the glass surface has proven challenging. Finally, we have focused solely on plasma EV measurements. 
medRxiv preprint doi: https://doi.org/10.1101/2021.09.26.21263660; this version posted September 27, 2021. The copyright holder for this preprint (which was not certified by peer review) is the author/funder, who has granted medRxiv a license to display the preprint in perpetuity. All rights reserved. No reuse allowed without permission.

It is entirely possible to perform similar measurements in pancreatic duct fluid. This could help improve the dilution problem that occurs when tEV are shed into circulation.

In summary, we show that single EV analysis is clinically feasible, powerful and essential in detecting rare proteins in EV that can be indicative of disease. We expect that this approach could be combined with state-of-the-art imaging to improve diagnostic accuracy in cancer detection. We also hope that the approach could be coused with synthetic biopsies and synthetic biomarkers to further improve accuracy.

\section{Materials and Methods \\ Cells}

AsPC-1, Capan-2, MIA PaCa-2, and PANC-1 were obtained from ATCC (Manassas, VA) (42). Patient derived xenograft cell lines were developed in the lab of Dr. Carlos Fernandez at $\operatorname{MGH}(9,43)$. All cell were characterized by mutational analysis, flow cytometry and immunofluorescence (Table 1).

\section{Cell culture}

AsPC-1, Capan-2, MIA PaCa-2, and PANC-1 cells were grown in DMEM supplemented with $10 \%$ FBS. Media was changed every $1-2$ days and cells were passaged prior to confluency. Patient derived cell lines were grown in 50:50 DMEM:F-12 media supplemented with $10 \%$ FBS and penicillin / streptomycin. Media was also changed every other day but cells were allowed to reach confluency. After each patient derived cell line reached confluency media was collected every other day for 7 days (four collection points) for EV isolation. The total cells were counted for each plate along with noting the collection interval to calculate EV shed rate in units of Day-1 (Fig. S4). For clonal expansion experiments a cross diagonal dilution strategy on a 96-well plate to obtain on-diagonal single-cell wells was employed as described (https:// www.corning.com/catalog/cls/documents/protocols/Single_cell_cloning_protocol.pdf) for AsPC-1, Capan-2, MIA PaCa-2, and PANC-1 cells. It is known that not all cell lines are capable of forming clones from a single cell. Capan-2 demonstrated this tendency with establishment of culture expansion predominantly in wells seeded with $>3$ cells. While MIA PaCa-2 established single-cell colonies, they quickly stopped expanding and appeared to enter contact-initiated senescence, passaging the colonies did not induce proliferation and the scant EV material collected was insufficient for analysis. Both AsPC-1 and PANC-1 were capable of forming several single cell colonies that after 6weeks could be passaged to 6-well plates and demonstrated easy to observe morphological differences. 6 clones for each AsPC-1 and PANC-1 were grown on $10 \mathrm{~cm}$ dishes and EV were collected as described.

\section{EV isolation}

EVs were isolated from cell culture media in a standard sequential approach. First, culture media was spun at $500 \mathrm{~g}$ for 5 minutes to remove cells and large cellular debris, the supernatant was then spun at $2000 \mathrm{~g}$ for 10 minutes for removal of apoptotic blebs and other micron-sized cellular material. The supernatant was then ultracentrifuged using the Beckman Coulter Optima-L-90K ultracentrifuge with the SW 32 Ti rotor, 
medRxiv preprint doi: https://doi.org/10.1101/2021.09.26.21263660; this version posted September 27, 2021. The copyright holder for this preprint (which was not certified by peer review) is the author/funder, who has granted medRxiv a license to display the preprint in perpetuity. All rights reserved. No reuse allowed without permission.

spinning at $24200 \mathrm{rpm}$ for 70 minutes. Total cell-culture media per sample isolated in this manner was typically $30-100 \mathrm{ml}$. The EV pellets were decanted of supernatant and left inverted until all residual media could be quickly wicked off the centrifuge tube inner wall with a Kimwipe. EV pellets for each sample were then pooled by serially resuspending with $100 \mu \mathrm{l}$ of 0.22 um filtered PBS. Since ultracentrifugation can co-pellet non-vesicle material, concentrated samples from resuspension were further purified on Izon 70nm qEV single columns following the manufacturer protocol. Clinical plasma samples stored at $-80^{\circ} \mathrm{C}$ were thawed on ice, and $100 \mu \mathrm{l}$ of each was spun at $10000 \mathrm{~g}$ for 20 minutes. The supernatant was carefully pipetted to avoid the loose pellet and was similarly isolated on an Izon 70nm qEV single size exclusion column. EV concentrations for cell culture samples obtained from the columns were typically of sufficient concentration as measured by the Qubit protein assay for downstream applications, however this was not the case for clinical samples. For any samples of insufficient concentration ( $<50 \mathrm{ng} / \mu \mathrm{l}$ protein concentration) the $650 \mu \mathrm{l}$ collection volume was concentrated on Nanosep Omega 300K MW cut-off concentrators.

\section{Clinical sample preparation}

All specimen were collected from patients referred to Massachusetts General Hospital with abdominal complaints and who gave informed consent. The study was approved by the Massachusetts General Hospital IRB. A total of $n=25$ patient samples were studied including healthy controls $(n=5)$, surgically proven stage 1 PDAC $(n=16)$, biopsy proven stage 2/4 PDAC ( $n=4$; Table 3). Blood collection was optimized for plasma EV analysis and all samples were de-identified and analyzed in blinded fashion. Briefly, whole blood was collected in one 10-mL purple-top EDTA tube and was inverted 10 times to mix. Whole blood was stored upright at $4^{\circ} \mathrm{C}$ and processed within 1 hour of collection. To process blood for plasma isolation, the tube was centrifuged for 10 min at $400 \times \mathrm{g}\left(4^{\circ} \mathrm{C}\right)$. The plasma layer was collected in a $15 \mathrm{~mL}$ tube using a pipette so as not to disturb the buffy coat. Plasma was then centrifuged for $10 \mathrm{~min}$ at $1100 \times \mathrm{g}\left(4^{\circ} \mathrm{C}\right)$. The plasma was then aliquoted into $1 \mathrm{~mL}$ aliquots and stored at $-80^{\circ} \mathrm{C}$.

\section{pan-EV labeling with fluorescent TFP}

Azido-dPEG ${ }_{12}$-TFP ester obtained from Quanta Bio-design was reacted in house with different DBCO Alexa Fluor (AF) fluorophores (AF350, AF488, and AF647 were all validated) obtained from Click Chemistry Tools. 1.1 molar equivalents of Azido-dPEG ${ }_{12}-$ TFP (dissolved in anhydrous DMSO to a stock concentration of $15 \mathrm{mg} / \mathrm{ml}$ ) and 1 molar equivalent of AlexaFluor DBCO dye (total $1 \mathrm{mg}$ of dye obtained from the manufacturer dissolved in $50 \mu \mathrm{l}$ of anhydrous DMSO) were combined for each reaction and incubated for 1 hour. The final coupling reaction concentrations thus varied by dye, ranging from 9 - 28mM in the reaction mix. The copper-free Azido-DBCO click chemistry reaction was confirmed to have gone to completion and to have generated the correct product by LCMS analysis. Dye-PEG $12-$ TFP conjugates retain amine reactivity through the TFPester and were incubated with EV samples for general surface-protein labeling. In most cases, 250ng of EV were combined with $1 \mu \mathrm{l}$ of the Dye-PEG ${ }_{12}-\mathrm{TFP}$. This ratio was scalable up to 1500ng EV input. The EV and Dye-PEG ${ }_{12}-T F P$ reactions were brought to a final volume of $14 \mu \mathrm{l}$ with filtered PBS and incubated in $1.5 \mathrm{ml}$ Eppendorf tubes protected from light and under agitation using a HulaMixer for 2 hours at room 
medRxiv preprint doi: https://doi.org/10.1101/2021.09.26.21263660; this version posted September 27, 2021. The copyright holder for this preprint (which was not certified by peer review) is the author/funder, who has granted medRxiv a license to display the preprint in perpetuity. All rights reserved. No reuse allowed without permission.

temperature. Excess Dye-PEG 12 -TFP was removed using ZebaTM Micro Spin Desalting Columns, 40K MWCO, $75 \mu \mathrm{L}$ according to the manufacturer protocol. For EV samples $>250$ ng labeled with $>1.0 \mu$ l Dye-PEG-TFP a second Zeba column purification to fully remove free dye signal was required.

\section{Antibody Labeling of TFP-stained EV}

While EV from cell culture could be reliably labeled and detected by AF350, this dye produced the dimmest signal and was sometimes insufficient for robust identification of EV derived from clinical samples. AF488 and AF647 worked well even for clinical samples for the conditions described above, however for downstream detection of protein markers with 680nm-labeled antibodies the AF647 TFP label showed bleed through into this channel at the exposure times necessary to detect lower antibody signals. Therefore, samples were labeled by AF488-TFP. Care was taken to avoid channel bleed through by optimizing filter choices and excitation light sources. A quantitation of channel bleed through and detection of fluorescent dyes is provided in Fig. S2)

EV labeled with AF488-TFP were used for the cell line antibody panel. The optimized antibody panel included anti-pan-mutant P53 detection antibody (Abcam, ab247264) conjugated to AF555, anti-G12V KRAS (Cell Signaling, 14412BF, special carrier-free order) and anti-G12D (Genetex, GTX635362), both labeled with AF594 using the Alexa Fluor 594 Antibody Labeling Kit from Thermo Fisher Scientific, as well as anti-Prolyl 4Hydroxylated $\alpha$ FG-P4OH (Diagnocine, KC600), anti-MUC1 (BioLegend, 355602), and anti-EGFR (Abcam, Ab30) conjugated to AF680 using the Alexa Fluor 680 Antibody Labeling Kit from Thermo Fisher Scientific (Table 3). All samples were processed with the following optimized protocol: $14 \mu \mathrm{l}$ of TFP-labeled EV were combined with $13 \mathrm{nM}$ antibody and $0.001 \%$ Triton-X-100 in 100 $\mu$ final volume of UltraBlock buffer (Bio-Rad, BUF033). Samples were then gently sonicated in a water bath for 5 minutes. The addition of $0.001 \%$ Triton-X-100 and sonication steps were necessary for intra-vesicular targets such as P53mut since they reportedly permeabilize EV without disrupting vesicle integrity; these steps were not necessary to obtain efficient staining of surface markers such as MUC1 and EGFR. For speciation of onco-proteins in clinical samples, EV were labeled with AF647-TFP and P53mut antibody was labeled with AF488 while the KRASG12D antibody was labeled with AF594. Samples were wrapped in foil to protect from photo-bleaching and were incubated on the HulaMixer overnight at 4C. In less optimal protocols ( 1 hour or less) bench top incubation also provided strong staining of several markers but at marginally reduced sensitivity and specificity.

\section{Sample Preparation for sEVA}

EV samples with fluorescently labeled antibodies were cleaned on the Izon 70nm qEV single size exclusion columns as described previously which allowed for significant reduction in background noise otherwise coming from free fluorescent antibody which is instead retained on the column. The $\sim 600-700 \mu l$ purified and labeled EV were filtered by $0.2 \mu \mathrm{m}$ PVDF $17 \mathrm{~mm}$ syringe filters and then concentrated using Nanosep Omega 300K MW cut-off devices. In contrast to other MW cut-off filter devices, Nanosep Omega resulted in lower EV loss, perhaps due to less extensive fouling. While this loss 
medRxiv preprint doi: https://doi.org/10.1101/2021.09.26.21263660; this version posted September 27, 2021. The copyright holder for this preprint (which was not certified by peer review) is the author/funder, who has granted medRxiv a license to display the preprint in perpetuity. All rights reserved. No reuse allowed without permission.

observed for other MW cut-off devices could be largely reversed by stringent washing of the filter membrane, this appeared to introduce large fibrous artifacts into the sample. Samples were concentrated near to the dead-stop volume of the devices $(\sim 30-50 \mu l)$. The concentrated samples with initial EV input of 250ng were then measured for total volume. A volume representing 100ng EV (typically $\sim 12-20 \mu \mathrm{l}$, assuming no EV loss) was carefully pipetted onto a well of a 21-well polytetrafluoroethylene (PTFE) hydrophobically printed glass slide from Electron Microscopy Sciences (63429-04). Samples were incubated under humidified and light-protected conditions for 30 minutes by placing a wet Kimwipe under an opaque box along with the slide. After 30 minutes, a majority of the sample droplet was carefully pipetted off so that the surface tension of remaining volume was level with the well-depth but still sufficient volume to wet the entirety of the well area. A glass coverslip was then placed onto the slide and images were promptly acquired.

\section{Imaging and Image Processing}

Images were acquired on an upright Olympus BX63 microscope using a 40x objective. EVs were brought into sharp focus with the FITC filter set allowing visualization of the TFP-labeled vesicles and 4000ms long exposure was used for acquisition. Proper focusing is critical since lower-signal nano-sized EVs can be lost even with minor changes in the z-plane settings. To ensure ideal focusing the live image display was monitored by looking at the smaller/dimmer EVs and manually tweaking until a minimum pixel-radius was observed. Field of view selection was performed only on the FITC channel to minimize marker signal biases. Suitable FOVs were observed across the majority of each well but in general near-perimeter areas were avoided as were areas of uneven background intensity (sometimes caused by small air bubbles, surface scratches, or crystallization patterning). After obtaining the total EV-TFP image the samples were also imaged for $4000 \mathrm{~ms}$ with the Texas Red filter set for KRASmut and P53mut detection and 4000ms with the CY5.5 filter set for EGFR, MUC1, and $\alpha F G$ $\mathrm{P} 4 \mathrm{OH}$ detection. EVs were thresholded according to the range of TFP-labeling which varied across clinical samples by taking a ratio of the brightest (90th percentile pixels) to the background (10th percentile pixels). In this way, the number of TFP-identifiable EV per FOV, along with average EV size, and therefore total percent coverage of EV could be standardized across images in line with the standardized amount of EV deposited per slide. Built-in particle analysis of particles larger than 5-pixels were then added into a region-of-interest (ROI) mask. This mask was applied to the background subtracted Texas Red and CY5.5 images corresponding to that sample and the signal intensities contained on TFP-EVs were measured. These measurements were then saved into comma delimited .CSV files to be analyzed. Receiver operator characteristic analysis was used to maximize the sensitivity and specificity between positive and negative control samples. For cell lines, marker positive cells and marker negative cells were used to establish these thresholds. For clinical samples healthy controls were used to establish a negative threshold. For a more detailed computational analysis protocol see Fig. S3. 
medRxiv preprint doi: https://doi.org/10.1101/2021.09.26.21263660; this version posted September 27, 2021. The copyright holder for this preprint (which was not certified by peer review) is the author/funder, who has granted medRxiv a license to display the preprint in perpetuity. All rights reserved. No reuse allowed without permission.

\section{Statistics}

Biomarker positive EV were summarized and expressed as the logarithm of the percent of total labeled EV per each clinical sample Log-normalized distributions passed the Shapiro-Wilk test for normality and statistically significant differences between groups were determined by one-way ANOVA assuming a normal distribution. Each marker set was compared to healthy controls for both early and late PDAC and multiple comparisons were corrected by Bonferroni's multiple comparisons test. Multiplicity adjusted p-values were indicated by significance: $0.0332\left(^{*}\right), 0.0021\left(^{* *}\right), 0.0002\left(^{* * *}\right)$, $\left.<0.0001{ }^{* * * *}\right)$. All statistics were performed in GraphPad Prism 8.0.

\section{Modeling and Simulation}

A modified model previously described(56) was used to simulate tumor-originating EV in circulation as a function of tumor size (Table 5, Fig. S4). In order to simulate across the range of expected tumor-EV shedding, the shed rate observed for patient-derived $2 \mathrm{D}$ cultures was corrected to account for the higher shed rate observed when cells grow in 3-dimensions, and this distribution was then checked for normality or log-normality. Across the seven patient cell lines observed, the data was, as expected, more closely representative of a log-normal distribution, passing both the Shapiro-Wilk and Kolmogorov-Smirnov test. For marker coverage observations however, the data for all cell lines tested passed each built-in Normality test within GraphPad Prism 8.0 and the likelihood ratio for normality (96.7\%) versus log normal (3.3\%) was 29.3. Therefore, when simulating 100 representative individuals a log-normal distribution of tEV shedding centered on 0.06597 Day $^{-1}$ with a standard deviation of 0.06269 was generated. For marker coverage, a normal distribution with a mean of $37.1 \%$ and standard deviation of 15.65 was simulated. For the simulation, some correlation within the lower triangular matrix was included following the observation that higher-EV shed rates were often accompanied by higher marker coverage as well as faster growth rate (covariance 0.35 ) (Additional time-variant error of $20 \%$ was included in the simulation and model outputs of tumor size and total tEV in circulation were then plotted. The total tEV in circulation was normalized to the percentage of tEV relative to all EV (tEV $+h E V)$ by hEV equal to $4.2 \mathrm{E} 7$ and dividing by the volume of distribution, $6000 \mathrm{ml}$. The total marker-positive tEV was computed by assigning the simulated distribution. The observed LOD for the combined marker panel of $0.005 \%$ was then set as a threshold and for each simulated sampling time a percentage of individuals above this threshold was computed and this data was fit to a Hill equation.

\section{Acknowledgments}

We thank Drs. Jeremy Quintana for performing LC-MS experiments on TFP reagents and Hakho Lee for helpful discussions. This work was supported in part by the following $\mathrm{NIH}$ grants: R01CA237332 (NCl), R01CA204019 (NCl), R21CA236561 (NCl), P01CA069246 ( $\mathrm{NCl})$.

\section{Contributions}

Design: SF, KY, RW

Experiments: SF, KY 
medRxiv preprint doi: https://doi.org/10.1101/2021.09.26.21263660; this version posted September 27, 2021. The copyright holder for this

PDX cell lines: ASL, CFC

Clinical samples: CFC, KY

Data analysis: SF, all authors

Writing: RW, SF, KY, all authors

\section{Conflict of interest}

None

\section{References}

1. L. Rahib, B. D. Smith, R. Aizenberg, A. B. Rosenzweig, J. M. Fleshman, L. M. Matrisian, Projecting cancer incidence and deaths to 2030: the unexpected burden of thyroid, liver, and pancreas cancers in the United States. Cancer Res 74, 29132921 (2014).

2. C. R. Ferrone, G. Marchegiani, T. S. Hong, D. P. Ryan, V. Deshpande, E. I. McDonnell, F. Sabbatino, D. D. Santos, J. N. Allen, L. S. Blaszkowsky, J. W. Clark, J. E. Faris, L. Goyal, E. L. Kwak, J. E. Murphy, D. T. Ting, J. Y. Wo, A. X. Zhu, A. L. Warshaw, K. D. Lillemoe, C. Fernández-del Castillo, Radiological and surgical implications of neoadjuvant treatment with FOLFIRINOX for locally advanced and borderline resectable pancreatic cancer. Ann Surg 261, 12-17 (2015).

3. A. K. Mattox, C. Bettegowda, S. Zhou, N. Papadopoulos, K. W. Kinzler, B. Vogelstein, Applications of liquid biopsies for cancer. Sci Transl Med 11, (2019).

4. B. A. Krantz, E. M. O'Reilly, Biomarker-Based Therapy in Pancreatic Ductal Adenocarcinoma: An Emerging Reality. Clin Cancer Res 24, 2241-2250 (2018).

5. C. Bettegowda, M. Sausen, R. J. Leary, I. Kinde, Y. Wang, N. Agrawal, B. R. Bartlett, H. Wang, B. Luber, R. M. Alani, E. S. Antonarakis, N. S. Azad, A. Bardelli, H. Brem, J. L. Cameron, C. C. Lee, L. A. Fecher, G. L. Gallia, P. Gibbs, D. Le, R. L. Giuntoli, M. Goggins, M. D. Hogarty, M. Holdhoff, S. M. Hong, Y. Jiao, H. H. Juhl, J. J. Kim, G. Siravegna, D. A. Laheru, C. Lauricella, M. Lim, E. J. Lipson, S. K. Marie, G. J. Netto, K. S. Oliner, A. Olivi, L. Olsson, G. J. Riggins, A. Sartore-Bianchi, K. Schmidt, L. M. Shih, S. M. Oba-Shinjo, S. Siena, D. Theodorescu, J. Tie, T. T. Harkins, S. Veronese, T. L. Wang, J. D. Weingart, C. L. Wolfgang, L. D. Wood, D. Xing, R. H. Hruban, J. Wu, P. J. Allen, C. M. Schmidt, M. A. Choti, V. E. Velculescu, K. W. Kinzler, B. Vogelstein, N. Papadopoulos, L. A. Diaz, Detection of circulating tumor DNA in early- and late-stage human malignancies. Sci Trans/ Med 6, 224 ra24 (2014).

6. J. D. Cohen, L. Li, Y. Wang, C. Thoburn, B. Afsari, L. Danilova, C. Douville, A. A. Javed, F. Wong, A. Mattox, R. H. Hruban, C. L. Wolfgang, M. G. Goggins, M. Dal Molin, T. L. Wang, R. Roden, A. P. Klein, J. Ptak, L. Dobbyn, J. Schaefer, N. Silliman, M. Popoli, J. T. Vogelstein, J. D. Browne, R. E. Schoen, R. E. Brand, J. Tie, P. Gibbs, H. L. Wong, A. S. Mansfield, J. Jen, S. M. Hanash, M. Falconi, P. J. Allen, S. Zhou, C. Bettegowda, L. A. Diaz, C. Tomasetti, K. W. Kinzler, B. Vogelstein, A. M. Lennon, N. Papadopoulos, Detection and localization of surgically resectable cancers with a multi-analyte blood test. Science (2018). 
medRxiv preprint doi: https://doi.org/10.1101/2021.09.26.21263660; this version posted September 27, 2021. The copyright holder for this preprint (which was not certified by peer review) is the author/funder, who has granted medRxiv a license to display the preprint in perpetuity. All rights reserved. No reuse allowed without permission.

7. B. Lee, L. Lipton, J. Cohen, J. Tie, A. A. Javed, L. Li, D. Goldstein, M. Burge, P. Cooray, A. Nagrial, N. C. Tebbutt, B. Thomson, M. Nikfarjam, M. Harris, A. Haydon, B. Lawrence, D. W. M. Tai, K. Simons, A. M. Lennon, C. L. Wolfgang, C. Tomasetti, N. Papadopoulos, K. W. Kinzler, B. Vogelstein, P. Gibbs, Circulating tumor DNA as a potential marker of adjuvant chemotherapy benefit following surgery for localized pancreatic cancer. Ann Oncol 30, 1472-1478 (2019).

8. A. D. Singhi, L. D. Wood, Early detection of pancreatic cancer using DNA-based molecular approaches. Nat Rev Gastroenterol Hepatol 18, 457-468 (2021).

9. K. S. Yang, H. Im, S. Hong, I. Pergolini, A. F. Del Castillo, R. Wang, S. Clardy, C. H. Huang, C. Pille, S. Ferrone, R. Yang, C. M. Castro, H. Lee, C. F. Del Castillo, R. Weissleder, Multiparametric plasma EV profiling facilitates diagnosis of pancreatic malignancy. Sci Transl Med 9, (2017).

10. V. Martini, S. Timme-Bronsert, S. Fichtner-Feigl, J. Hoeppner, B. Kulemann, Circulating Tumor Cells in Pancreatic Cancer: Current Perspectives. Cancers (Basel) 11, (2019).

11. C. Yuan, C. B. Clish, C. Wu, J. R. Mayers, P. Kraft, M. K. Townsend, M. Zhang, S. S. Tworoger, Y. Bao, Z. R. Qian, D. A. Rubinson, K. Ng, E. L. Giovannucci, S. Ogino, M. J. Stampfer, J. M. Gaziano, J. Ma, H. D. Sesso, G. L. Anderson, B. B. Cochrane, J. E. Manson, M. E. Torrence, A. C. Kimmelman, L. T. Amundadottir, M. G. Vander Heiden, C. S. Fuchs, B. M. Wolpin, Circulating Metabolites and Survival Among Patients With Pancreatic Cancer. J Natl Cancer Inst 108, djv409 (2016).

12. H. Shao, H. Im, C. M. Castro, X. Breakefield, R. Weissleder, H. Lee, New Technologies for Analysis of Extracellular Vesicles. Chem Rev 118, 1917-1950 (2018).

13. H. Im, H. Shao, Y. I. Park, V. M. Peterson, C. M. Castro, R. Weissleder, H. Lee, Label-free detection and molecular profiling of exosomes with a nano-plasmonic sensor. Nat Biotechnol 32, 490-495 (2014).

14. D. Issadore, C. Min, M. Liong, J. Chung, R. Weissleder, H. Lee, Miniature magnetic resonance system for point-of-care diagnostics. Lab Chip 11, 2282-2287 (2011).

15. H. Lee, E. Sun, D. Ham, R. Weissleder, Chip-NMR biosensor for detection and molecular analysis of cells. Nat Med 14, 869-874 (2008).

16. T. Arab, E. R. Mallick, Y. Huang, L. Dong, Z. Liao, Z. Zhao, O. Gololobova, B. Smith, N. J. Haughey, K. J. Pienta, B. S. Slusher, P. M. Tarwater, J. P. Tosar, A. M. Zivkovic, W. N. Vreeland, M. E. Paulaitis, K. W. Witwer, Characterization of extracellular vesicles and synthetic nanoparticles with four orthogonal singleparticle analysis platforms. J Extracell Vesicles 10, e12079 (2021).

17. K. Lee, K. Fraser, B. Ghaddar, K. Yang, E. Kim, L. Balaj, A. Chiocca, X. O. Breakefield, H. Lee, R. Weissleder, Multiplexed Profiling of Single Extracellular Vesicles. ACS Nano (2017).

18. S. A. Melo, L. B. Luecke, C. Kahlert, A. F. Fernandez, S. T. Gammon, J. Kaye, V. S. LeBleu, E. A. Mittendorf, J. Weitz, N. Rahbari, C. Reissfelder, C. Pilarsky, M. F. Fraga, D. Piwnica-Worms, R. Kalluri, Glypican-1 identifies cancer exosomes and detects early pancreatic cancer. Nature 523, 177-182 (2015).

19. M. Capello, L. E. Bantis, G. Scelo, Y. Zhao, P. Li, D. S. Dhillon, N. J. Patel, D. L. Kundnani, H. Wang, J. L. Abbruzzese, A. Maitra, M. A. Tempero, R. Brand, M. A. Firpo, S. J. Mulvihill, M. H. Katz, P. Brennan, Z. Feng, A. Taguchi, S. M. Hanash, 
medRxiv preprint doi: https://doi.org/10.1101/2021.09.26.21263660; this version posted September 27, 2021. The copyright holder for this preprint (which was not certified by peer review) is the author/funder, who has granted medRxiv a license to display the preprint in perpetuity. All rights reserved. No reuse allowed without permission.

Sequential Validation of Blood-Based Protein Biomarker Candidates for EarlyStage Pancreatic Cancer. J Natl Cancer Inst 109, (2017).

20. J. Kim, W. R. Bamlet, A. L. Oberg, K. G. Chaffee, G. Donahue, X. J. Cao, S. Chari, B. A. Garcia, G. M. Petersen, K. S. Zaret, Detection of early pancreatic ductal adenocarcinoma with thrombospondin-2 and CA19-9 blood markers. Sci Transl Med 9, eaah5583 (2017).

21. S. A. Hinger, J. J. Abner, J. L. Franklin, D. K. Jeppesen, R. J. Coffey, J. G. Patton, Rab13 regulates sEV secretion in mutant KRAS colorectal cancer cells. Sci Rep 10, 15804 (2020).

22. K. H. Lim, K. O’Hayer, S. J. Adam, S. D. Kendall, P. M. Campbell, C. J. Der, C. M. Counter, Divergent roles for RalA and RalB in malignant growth of human pancreatic carcinoma cells. Curr Biol 16, 2385-2394 (2006).

23. K. H. Lim, A. T. Baines, J. J. Fiordalisi, M. Shipitsin, L. A. Feig, A. D. Cox, C. J. Der, C. M. Counter, Activation of RalA is critical for Ras-induced tumorigenesis of human cells. Cancer Cell 7, 533-545 (2005).

24. S. Zhang, C. Wang, B. Ma, M. Xu, S. Xu, J. Liu, Y. Tian, Y. Fu, Y. Luo, Mutant p53 Drives Cancer Metastasis via RCP-Mediated Hsp90a Secretion. Cell Rep 32, 107879 (2020).

25. H. Ying, P. Dey, W. Yao, A. C. Kimmelman, G. F. Draetta, A. Maitra, R. A. DePinho, Genetics and biology of pancreatic ductal adenocarcinoma. Genes Dev 30, 355385 (2016).

26. A. M. Waters, C. J. Der, KRAS: The Critical Driver and Therapeutic Target for Pancreatic Cancer. Cold Spring Harb Perspect Med 8, (2018).

27. J. Kowal, G. Arras, M. Colombo, M. Jouve, J. P. Morath, B. Primdal-Bengtson, F. Dingli, D. Loew, M. Tkach, C. Théry, Proteomic comparison defines novel markers to characterize heterogeneous populations of extracellular vesicle subtypes. Proc Natl Acad Sci U S A 113, E968-77 (2016).

28. S. Springer, Y. Wang, M. Dal Molin, D. L. Masica, Y. Jiao, I. Kinde, A. Blackford, S. P. Raman, C. L. Wolfgang, T. Tomita, N. Niknafs, C. Douville, J. Ptak, L. Dobbyn, P. J. Allen, D. S. Klimstra, M. A. Schattner, C. M. Schmidt, M. Yip-Schneider, O. W. Cummings, R. E. Brand, H. J. Zeh, A. D. Singhi, A. Scarpa, R. Salvia, G. Malleo, G. Zamboni, M. Falconi, J. Y. Jang, S. W. Kim, W. Kwon, S. M. Hong, K. B. Song, S. C. Kim, N. Swan, J. Murphy, J. Geoghegan, W. Brugge, C. Fernandez-Del Castillo, M. Mino-Kenudson, R. Schulick, B. H. Edil, V. Adsay, J. Paulino, J. van Hooft, S. Yachida, S. Nara, N. Hiraoka, K. Yamao, S. Hijioka, S. van der Merwe, M. Goggins, M. I. Canto, N. Ahuja, K. Hirose, M. Makary, M. J. Weiss, J. Cameron, M. Pittman, J. R. Eshleman, L. A. Diaz, N. Papadopoulos, K. W. Kinzler, R. Karchin, R. H. Hruban, B. Vogelstein, A. M. Lennon, A combination of molecular markers and clinical features improve the classification of pancreatic cysts.

Gastroenterology 149, 1501-1510 (2015).

29. G. A. R. N. E. A. A. Cancer, G. A. R. N. Cancer, Integrated Genomic Characterization of Pancreatic Ductal Adenocarcinoma. Cancer Cell 32, 185203.e13 (2017).

30. N. Koshikawa, T. Minegishi, H. Kiyokawa, M. Seiki, Specific detection of soluble EphA2 fragments in blood as a new biomarker for pancreatic cancer. Cell Death Dis 8, e3134 (2017). 
medRxiv preprint doi: https://doi.org/10.1101/2021.09.26.21263660; this version posted September 27, 2021. The copyright holder for this preprint (which was not certified by peer review) is the author/funder, who has granted medRxiv a license to display the preprint in perpetuity. All rights reserved. No reuse allowed without permission.

31. L. Gambini, A. F. Salem, P. Udompholkul, X. F. Tan, C. Baggio, N. Shah, A. Aronson, J. Song, M. Pellecchia, Structure-Based Design of Novel EphA2 Agonistic Agents with Nanomolar Affinity in Vitro and in Cell. ACS Chem Biol 13, 2633-2644 (2018).

32. S. Boeck, C. Wittwer, V. Heinemann, M. Haas, C. Kern, P. Stieber, D. Nagel, S. Holdenrieder, Cytokeratin 19-fragments (CYFRA 21-1) as a novel serum biomarker for response and survival in patients with advanced pancreatic cancer. $\mathrm{Br} \mathrm{J}$ Cancer 108, 1684-1694 (2013).

33. D. Bausch, M. Mino-Kenudson, C. Fernández-Del Castillo, A. L. Warshaw, K. A. Kelly, S. P. Thayer, Plectin-1 is a biomarker of malignant pancreatic intraductal papillary mucinous neoplasms. J Gastrointest Surg 13, 1948-54; discussion 1954 (2009).

34. R. Chen, E. C. Yi, S. Donohoe, S. Pan, J. Eng, K. Cooke, D. A. Crispin, Z. Lane, D. R. Goodlett, M. P. Bronner, R. Aebersold, T. A. Brentnall, Pancreatic cancer proteome: the proteins that underlie invasion, metastasis, and immunologic escape. Gastroenterology 129, 1187-1197 (2005).

35. K. Suzuki, A. Watanabe, K. Araki, T. Yokobori, N. Harimoto, D. Gantumur, K. Hagiwara, T. Yamanaka, N. Ishii, M. Tsukagoshi, T. Igarashi, N. Kubo, N. Gombodorj, M. Nishiyama, Y. Hosouchi, H. Kuwano, K. Shirabe, High STMN1 Expression Is Associated with Tumor Differentiation and Metastasis in Clinical Patients with Pancreatic Cancer. Anticancer Res 38, 939-944 (2018).

36. I. Keklikoglou, C. Cianciaruso, E. Güç, M. L. Squadrito, L. M. Spring, S. Tazzyman, L. Lambein, A. Poissonnier, G. B. Ferraro, C. Baer, A. Cassará, A. Guichard, M. L. Iruela-Arispe, C. E. Lewis, L. M. Coussens, A. Bardia, R. K. Jain, J. W. Pollard, M. De Palma, Chemotherapy elicits pro-metastatic extracellular vesicles in breast cancer models. Nat Cell Biol 21, 190-202 (2019).

37. S. Kaur, L. M. Smith, A. Patel, M. Menning, D. C. Watley, S. S. Malik, S. R. Krishn, K. Mallya, A. Aithal, A. R. Sasson, S. L. Johansson, M. Jain, S. Singh, S. Guha, C. Are, M. Raimondo, M. A. Hollingsworth, R. E. Brand, S. K. Batra, A Combination of MUC5AC and CA19-9 Improves the Diagnosis of Pancreatic Cancer: A Multicenter Study. Am J Gastroenterol 112, 172-183 (2017).

38. K. K. Das, X. Geng, J. W. Brown, V. Morales-Oyarvide, T. Huynh, I. Pergolini, M. B. Pitman, C. Ferrone, M. Al Efishat, D. Haviland, E. Thompson, C. Wolfgang, A. M. Lennon, P. Allen, K. D. Lillemoe, R. C. Fields, W. G. Hawkins, J. Liu, C. F. Castillo, K. M. Das, M. Mino-Kenudson, Cross Validation of the Monoclonal Antibody Das-1 in Identification of High-Risk Mucinous Pancreatic Cystic Lesions. Gastroenterology 157, 720-730.e2 (2019).

39. K. K. Das, H. Xiao, X. Geng, C. Fernandez-Del-Castillo, V. Morales-Oyarvide, E. Daglilar, D. G. Forcione, B. C. Bounds, W. R. Brugge, M. B. Pitman, M. MinoKenudson, K. M. Das, mAb Das-1 is specific for high-risk and malignant intraductal papillary mucinous neoplasm (IPMN). Gut 63, 1626-1634 (2014).

40. K. S. Yang, D. Ciprani, A. O'Shea, A. Liss, R. Yang, S. Fletcher-Mercaldo, M. MinoKenudson, C. Fernández-Del Castillo, R. Weissleder, Extracellular vesicle analysis allows for identification of invasive IPMN. Gastroenterology (2020).

41. C. Tian, K. R. Clauser, D. Öhlund, S. Rickelt, Y. Huang, M. Gupta, D. R. Mani, S. A. Carr, D. A. Tuveson, R. O. Hynes, Proteomic analyses of ECM during pancreatic 
medRxiv preprint doi: https://doi.org/10.1101/2021.09.26.21263660; this version posted September 27, 2021. The copyright holder for this preprint (which was not certified by peer review) is the author/funder, who has granted medRxiv a license to display the preprint in perpetuity. All rights reserved. No reuse allowed without permission.

ductal adenocarcinoma progression reveal different contributions by tumor and stromal cells. Proc Natl Acad Sci U S A 116, 19609-19618 (2019).

42. E. L. Deer, J. González-Hernández, J. D. Coursen, J. E. Shea, J. Ngatia, C. L. Scaife, M. A. Firpo, S. J. Mulvihill, Phenotype and genotype of pancreatic cancer cell lines. Pancreas 39, 425-435 (2010).

43. I. Pergolini, V. Morales-Oyarvide, M. Mino-Kenudson, K. C. Honselmann, M. W. Rosenbaum, S. Nahar, M. Kem, C. R. Ferrone, K. D. Lillemoe, N. Bardeesy, D. P. Ryan, S. P. Thayer, A. L. Warshaw, C. Fernández-Del Castillo, A. S. Liss, Tumor engraftment in patient-derived xenografts of pancreatic ductal adenocarcinoma is associated with adverse clinicopathological features and poor survival. PLoS One 12, e0182855 (2017).

44. M. Ono, J. Matsubara, K. Honda, T. Sakuma, T. Hashiguchi, H. Nose, S. Nakamori, T. Okusaka, T. Kosuge, N. Sata, H. Nagai, T. loka, S. Tanaka, A. Tsuchida, T. Aoki, M. Shimahara, Y. Yasunami, T. Itoi, F. Moriyasu, A. Negishi, H. Kuwabara, A. Shoji, S. Hirohashi, T. Yamada, Prolyl 4-hydroxylation of alpha-fibrinogen: a novel protein modification revealed by plasma proteomics. J Biol Chem 284, 29041-29049 (2009).

45. C. J. Mageean, J. R. Griffiths, D. L. Smith, M. J. Clague, I. A. Prior, Absolute Quantification of Endogenous Ras Isoform Abundance. PLoS One 10, e0142674 (2015).

46. S. Kitamoto, S. Yokoyama, M. Higashi, N. Yamada, S. Takao, S. Yonezawa, MUC1 enhances hypoxia-driven angiogenesis through the regulation of multiple proangiogenic factors. Oncogene 32, 4614-4621 (2013).

47. H. L. Huang, H. Y. Wu, P. C. Chu, I. L. Lai, P. H. Huang, S. K. Kulp, S. L. Pan, C. M. Teng, C. S. Chen, Role of integrin-linked kinase in regulating the protein stability of the MUC1-C oncoprotein in pancreatic cancer cells. Oncogenesis 6, e359 (2017).

48. M. Palviainen, M. Saraswat, Z. Varga, D. Kitka, M. Neuvonen, M. Puhka, S. Joenväärä, R. Renkonen, R. Nieuwland, M. Takatalo, P. R. M. Siljander, Extracellular vesicles from human plasma and serum are carriers of extravesicular cargo-Implications for biomarker discovery. PLoS One 15, e0236439 (2020).

49. J. Van Deun, A. Jo, H. Li, H. Y. Lin, R. Weissleder, H. Im, H. Lee, Integrated DualMode Chromatography to Enrich Extracellular Vesicles from Plasma. Adv Biosyst 4, e1900310 (2020).

50. M. Goggins, K. A. Overbeek, R. Brand, S. Syngal, M. Del Chiaro, D. K. Bartsch, C. Bassi, A. Carrato, J. Farrell, E. K. Fishman, P. Fockens, T. M. Gress, J. E. van Hooft, R. H. Hruban, F. Kastrinos, A. Klein, A. M. Lennon, A. Lucas, W. Park, A. Rustgi, D. Simeone, E. Stoffel, H. F. A. Vasen, D. L. Cahen, M. I. Canto, M. Bruno, C. O. T. P. S. C. A. P. S. C. International, Management of patients with increased risk for familial pancreatic cancer: updated recommendations from the International Cancer of the Pancreas Screening (CAPS) Consortium. Gut 69, 7-17 (2020).

51. R. Sharma, X. Huang, R. A. Brekken, A. J. Schroit, Detection of phosphatidylserine-positive exosomes for the diagnosis of early-stage malignancies. Br J Cancer 117, 545-552 (2017). 
medRxiv preprint doi: https://doi.org/10.1101/2021.09.26.21263660; this version posted September 27, 2021. The copyright holder for this preprint (which was not certified by peer review) is the author/funder, who has granted medRxiv a license to display the preprint in perpetuity. All rights reserved. No reuse allowed without permission.

52. V. H. Cruz, E. N. Arner, W. Du, A. E. Bremauntz, R. A. Brekken, Axl-mediated activation of TBK1 drives epithelial plasticity in pancreatic cancer. JCI Insight 5, 126117 (2019).

53. K. P. Olive, M. A. Jacobetz, C. J. Davidson, A. Gopinathan, D. Mclntyre, D. Honess, B. Madhu, M. A. Goldgraben, M. E. Caldwell, D. Allard, K. K. Frese, G. Denicola, C. Feig, C. Combs, S. P. Winter, H. Ireland-Zecchini, S. Reichelt, W. J. Howat, A. Chang, M. Dhara, L. Wang, F. Rückert, R. Grützmann, C. Pilarsky, K. Izeradjene, S. R. Hingorani, P. Huang, S. E. Davies, W. Plunkett, M. Egorin, R. H. Hruban, N. Whitebread, K. McGovern, J. Adams, C. lacobuzio-Donahue, J. Griffiths, D. A. Tuveson, Inhibition of Hedgehog signaling enhances delivery of chemotherapy in a mouse model of pancreatic cancer. Science 324, 1457-1461 (2009).

54. M. P. Zaborowski, L. Balaj, X. O. Breakefield, C. P. Lai, Extracellular Vesicles: Composition, Biological Relevance, and Methods of Study. Bioscience 65, 783797 (2015).

55. C. Théry, K. W. Witwer, E. Aikawa, M. J. Alcaraz, J. D. Anderson, R. Andriantsitohaina, A. Antoniou, T. Arab, F. Archer, G. K. Atkin-Smith, D. C. Ayre, J. M. Bach, D. Bachurski, H. Baharvand, L. Balaj, S. Baldacchino, N. N. Bauer, A. A. Baxter, M. Bebawy, C. Beckham, A. Bedina Zavec, A. Benmoussa, A. C. Berardi, P. Bergese, E. Bielska, C. Blenkiron, S. Bobis-Wozowicz, E. Boilard, W. Boireau, A. Bongiovanni, F. E. Borràs, S. Bosch, C. M. Boulanger, X. Breakefield, A. M. Breglio, M. Á. Brennan, D. R. Brigstock, A. Brisson, M. L. Broekman, J. F. Bromberg, P. Bryl-Górecka, S. Buch, A. H. Buck, D. Burger, S. Busatto, D. Buschmann, B. Bussolati, E. I. Buzás, J. B. Byrd, G. Camussi, D. R. Carter, S. Caruso, L. W. Chamley, Y. T. Chang, C. Chen, S. Chen, L. Cheng, A. R. Chin, A. Clayton, S. P. Clerici, A. Cocks, E. Cocucci, R. J. Coffey, A. Cordeiro-da-Silva, Y. Couch, F. A. Coumans, B. Coyle, R. Crescitelli, M. F. Criado, C. D'Souza-Schorey, S. Das, A. Datta Chaudhuri, P. de Candia, E. F. De Santana, O. De Wever, H. A. Del Portillo, T. Demaret, S. Deville, A. Devitt, B. Dhondt, D. Di Vizio, L. C. Dieterich, V. Dolo, A. P. Dominguez Rubio, M. Dominici, M. R. Dourado, T. A. Driedonks, F. V. Duarte, H. M. Duncan, R. M. Eichenberger, K. Ekström, S. El Andaloussi, C. ElieCaille, U. Erdbrügger, J. M. Falcón-Pérez, F. Fatima, J. E. Fish, M. Flores-Bellver, A. Försönits, A. Frelet-Barrand, F. Fricke, G. Fuhrmann, S. Gabrielsson, A. GámezValero, C. Gardiner, K. Gärtner, R. Gaudin, Y. S. Gho, B. Giebel, C. Gilbert, M. Gimona, I. Giusti, D. C. Goberdhan, A. Görgens, S. M. Gorski, D. W. Greening, J. C. Gross, A. Gualerzi, G. N. Gupta, D. Gustafson, A. Handberg, R. A. Haraszti, P. Harrison, H. Hegyesi, A. Hendrix, A. F. Hill, F. H. Hochberg, K. F. Hoffmann, B. Holder, H. Holthofer, B. Hosseinkhani, G. Hu, Y. Huang, V. Huber, S. Hunt, A. G. Ibrahim, T. Ikezu, J. M. Inal, M. Isin, A. Ivanova, H. K. Jackson, S. Jacobsen, S. M. Jay, M. Jayachandran, G. Jenster, L. Jiang, S. M. Johnson, J. C. Jones, A. Jong, T. Jovanovic-Talisman, S. Jung, R. Kalluri, S. I. Kano, S. Kaur, Y. Kawamura, E. T. Keller, D. Khamari, E. Khomyakova, A. Khvorova, P. Kierulf, K. P. Kim, T. Kislinger, M. Klingeborn, D. J. Klinke, M. Kornek, M. M. Kosanović, Á. F. Kovács, E. M. Krämer-Albers, S. Krasemann, M. Krause, I. V. Kurochkin, G. D. Kusuma, S. Kuypers, S. Laitinen, S. M. Langevin, L. R. Languino, J. Lannigan, C. Lässer, L. C. Laurent, G. Lavieu, E. Lázaro-Ibáñez, S. Le Lay, M. S. Lee, Y. X. F. Lee, D. S. 
medRxiv preprint doi: https://doi.org/10.1101/2021.09.26.21263660; this version posted September 27, 2021. The copyright holder for this preprint (which was not certified by peer review) is the author/funder, who has granted medRxiv a license to display the preprint in perpetuity. All rights reserved. No reuse allowed without permission.

Lemos, M. Lenassi, A. Leszczynska, I. T. Li, K. Liao, S. F. Libregts, E. Ligeti, R. Lim, S. K. Lim, A. Linē, K. Linnemannstöns, A. Llorente, C. A. Lombard, M. J. Lorenowicz, Á. M. Lörincz, J. Lötvall, J. Lovett, M. C. Lowry, X. Loyer, Q. Lu, B. Lukomska, T. R. Lunavat, S. L. Maas, H. Malhi, A. Marcilla, J. Mariani, J. Mariscal, E. S. Martens-Uzunova, L. Martin-Jaular, M. C. Martinez, V. R. Martins, M. Mathieu, S. Mathivanan, M. Maugeri, L. K. McGinnis, M. J. McVey, D. G. Meckes, K. L. Meehan, I. Mertens, V. R. Minciacchi, A. Möller, M. Møller Jørgensen, A. Morales-Kastresana, J. Morhayim, F. Mullier, M. Muraca, L. Musante, V. Mussack, D. C. Muth, K. H. Myburgh, T. Najrana, M. Nawaz, I. Nazarenko, P. Nejsum, C. Neri, T. Neri, R. Nieuwland, L. Nimrichter, J. P. Nolan, E. N. Nolte-'t Hoen, N. Noren Hooten, L. O'Driscoll, T. O'Grady, A. O'Loghlen, T. Ochiya, M. Olivier, A. Ortiz, L. A. Ortiz, X. Osteikoetxea, O. Østergaard, M. Ostrowski, J. Park, D. M. Pegtel, H. Peinado, F. Perut, M. W. Pfaffl, D. G. Phinney, B. C. Pieters, R. C. Pink, D. S. Pisetsky, E. Pogge von Strandmann, I. Polakovicova, I. K. Poon, B. H. Powell, I. Prada, L. Pulliam, P. Quesenberry, A. Radeghieri, R. L. Raffai, S. Raimondo, J. Rak, M. I. Ramirez, G. Raposo, M. S. Rayyan, N. Regev-Rudzki, F. L. Ricklefs, P. D. Robbins, D. D. Roberts, S. C. Rodrigues, E. Rohde, S. Rome, K. M. Rouschop, A. Rughetti, A. E. Russell, P. Saá, S. Sahoo, E. Salas-Huenuleo, C. Sánchez, J. A. Saugstad, M. J. Saul, R. M. Schiffelers, R. Schneider, T. H. Schøyen, A. Scott, E. Shahaj, S. Sharma, O. Shatnyeva, F. Shekari, G. V. Shelke, A. K. Shetty, K. Shiba, P. R. Siljander, A. M. Silva, A. Skowronek, O. L. Snyder, R. P. Soares, B. W. Sódar, C. Soekmadji, J. Sotillo, P. D. Stahl, W. Stoorvogel, S. L. Stott, E. F. Strasser, S. Swift, H. Tahara, M. Tewari, K. Timms, S. Tiwari, R. Tixeira, M. Tkach, W. S. Toh, R. Tomasini, A. C. Torrecilhas, J. P. Tosar, V. Toxavidis, L. Urbanelli, P. Vader, B. W. van Balkom, S. G. van der Grein, J. Van Deun, M. J. van Herwijnen, K. Van Keuren-Jensen, G. van Niel, M. E. van Royen, A. J. van Wijnen, M. H.

Vasconcelos, I. J. Vechetti, T. D. Veit, L. J. Vella, É. Velot, F. J. Verweij, B. Vestad, J. L. Viñas, T. Visnovitz, K. V. Vukman, J. Wahlgren, D. C. Watson, M. H. Wauben, A. Weaver, J. P. Webber, V. Weber, A. M. Wehman, D. J. Weiss, J. A. Welsh, S. Wendt, A. M. Wheelock, Z. Wiener, L. Witte, J. Wolfram, A. Xagorari, P. Xander, J. Xu, X. Yan, M. Yáñez-Mó, H. Yin, Y. Yuana, V. Zappulli, J. Zarubova, V. Žèkas, J. Y. Zhang, Z. Zhao, L. Zheng, A. R. Zheutlin, A. M. Zickler, P. Zimmermann, A. M. Zivkovic, D. Zocco, E. K. Zuba-Surma, Minimal information for studies of extracellular vesicles 2018 (MISEV2018): a position statement of the International Society for Extracellular Vesicles and update of the MISEV2014 guidelines. $J$ Extracell Vesicles 7, 1535750 (2018).

56. S. Ferguson, R. Weissleder, Modeling EV Kinetics for Use in Early Cancer Detection. Adv Biosyst 4, e1900305 (2020).

57. F. Pucci, C. Garris, C. P. Lai, A. Newton, C. Pfirschke, C. Engblom, D. Alvarez, M. Sprachman, C. Evavold, A. Magnuson, U. H. von Andrian, K. Glatz, X. O. Breakefield, T. R. Mempel, R. Weissleder, M. J. Pittet, SCS macrophages suppress melanoma by restricting tumor-derived vesicle-B cell interactions. Science $\mathbf{3 5 2}$, 242-246 (2016).

58. M. P. Bebelman, E. Janssen, D. M. Pegtel, C. Crudden, The forces driving cancer extracellular vesicle secretion. Neoplasia 23, 149-157 (2021). 
medRxiv preprint doi: https://doi.org/10.1101/2021.09.26.21263660; this version posted September 27, 2021. The copyright holder for this preprint (which was not certified by peer review) is the author/funder, who has granted medRxiv a license to display the preprint in perpetuity. All rights reserved. No reuse allowed without permission.

59. A. Datta, H. Kim, M. Lal, L. McGee, A. Johnson, A. A. Moustafa, J. C. Jones, D. Mondal, M. Ferrer, A. B. Abdel-Mageed, Manumycin A suppresses exosome biogenesis and secretion via targeted inhibition of Ras/Raf/ERK1/2 signaling and hnRNP H1 in castration-resistant prostate cancer cells. Cancer Lett 408, 73-81 (2017).

60. V. Hyenne, A. Apaydin, D. Rodriguez, C. Spiegelhalter, S. Hoff-Yoessle, M. Diem, S. Tak, O. Lefebvre, Y. Schwab, J. G. Goetz, M. Labouesse, RAL-1 controls multivesicular body biogenesis and exosome secretion. J Cell Biol 211, 27-37 (2015).

61. X. Yu, S. L. Harris, A. J. Levine, The regulation of exosome secretion: a novel function of the p53 protein. Cancer Res 66, 4795-4801 (2006).

62. A. Lespagnol, D. Duflaut, C. Beekman, L. Blanc, G. Fiucci, J. C. Marine, M. Vidal, R. Amson, A. Telerman, Exosome secretion, including the DNA damage-induced p53-dependent secretory pathway, is severely compromised in TSAP6/Steap3-null mice. Cell Death Differ 15, 1723-1733 (2008).

63. A. A. Shamseddine, C. J. Clarke, B. Carroll, M. V. Airola, S. Mohammed, A. Rella, L. M. Obeid, Y. A. Hannun, P53-dependent upregulation of neutral sphingomyelinase-2: role in doxorubicin-induced growth arrest. Cell Death Dis 6, e1947 (2015).

64. N. Bardeesy, A. J. Aguirre, G. C. Chu, K. H. Cheng, L. V. Lopez, A. F. Hezel, B. Feng, C. Brennan, R. Weissleder, U. Mahmood, D. Hanahan, M. S. Redston, L. Chin, R. A. Depinho, Both p16(Ink4a) and the p19(Arf)-p53 pathway constrain progression of pancreatic adenocarcinoma in the mouse. Proc Natl Acad Sci U S A 103, 5947-5952 (2006).

65. J. Ko, Y. Wang, J. C. T. Carlson, A. Marquard, J. Gungabeesoon, A. Charest, D. Weitz, M. J. Pittet, R. Weissleder, Single Extracellular Vesicle Protein Analysis Using Immuno-Droplet Digital Polymerase Chain Reaction Amplification. Adv Biosyst 4, e1900307 (2020).

66. J. Ko, Y. Wang, K. Sheng, D. A. Weitz, R. Weissleder, Sequencing-Based Protein Analysis of Single Extracellular Vesicles. ACS Nano 15, 5631-5638 (2021). 
medRxiv preprint doi: https://doi.org/10.1101/2021.09.26.21263660; this version posted September 27, 2021. The copyright holder for this preprint (which was not certified by peer review) is the author/funder, who has granted medRxiv a license to display the preprint in perpetuity.

All rights reserved. No reuse allowed without permission.

\section{Figures}

Fig. 1: Overview of sEVA. A) EV are labeled in solution with i) the protein reactive TFP dye (green) and ii) biomarker-specific fluorescent antibodies (red, far red (shown in blue)). B) Following purification to remove unbound TFP and fluorescent antibodies, the EV are C) pipetted onto hydrophobic glass sides and $\mathbf{D}, \mathbf{E})$ imaged and then analyzed.

See Fig. S1 for details on labeling and Fig. $\mathbf{S 2}$ for the computational analysis pipeline.
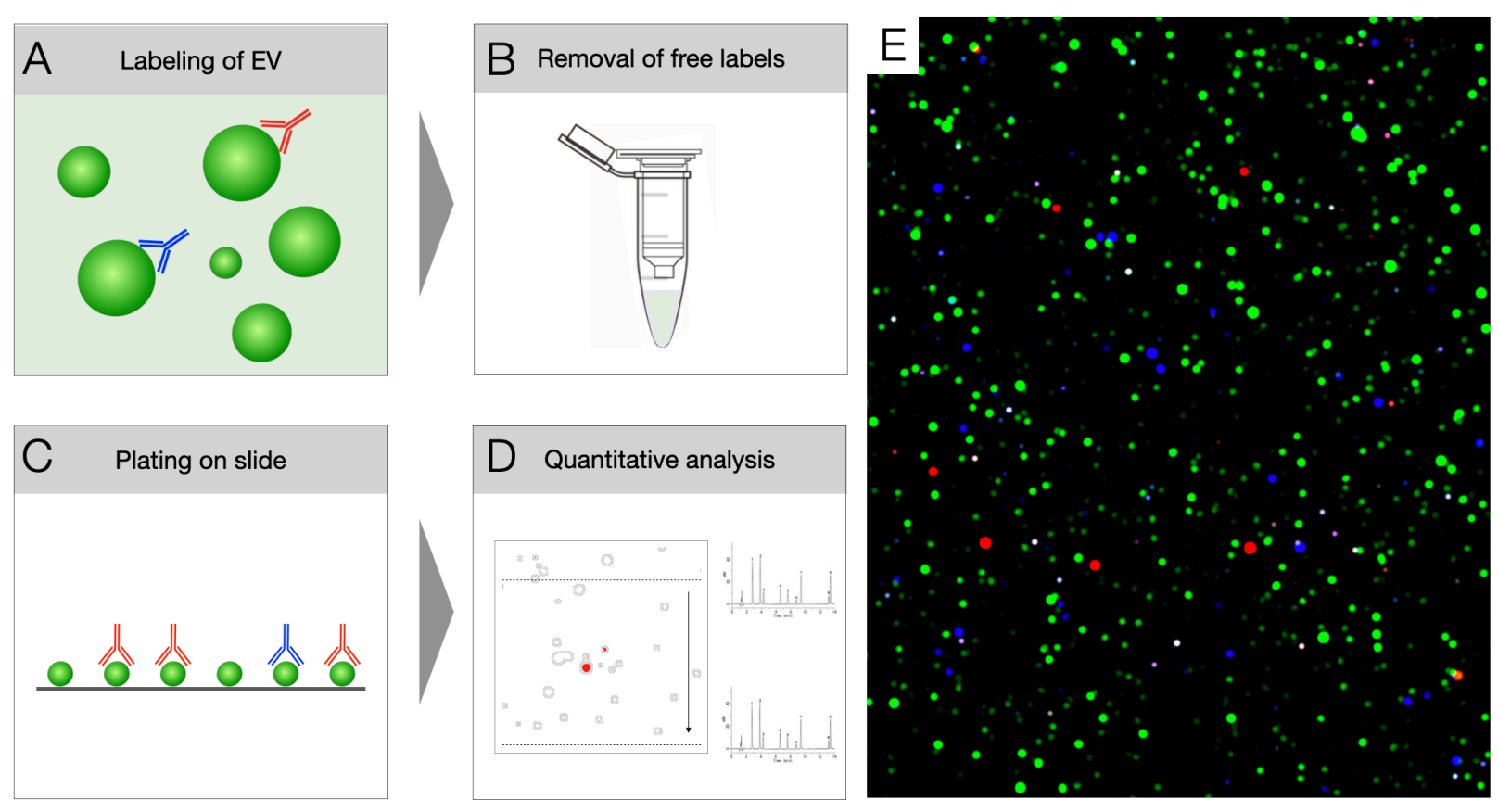
medRxiv preprint doi: https://doi.org/10.1101/2021.09.26.21263660; this version posted September 27, 2021. The copyright holder for this preprint (which was not certified by peer review) is the author/funder, who has granted medRxiv a license to display the preprint in perpetuity.

All rights reserved. No reuse allowed without permission.

Fig. 2: Workflow of single EV analysis A) In an initial screen, EV are labeled for pooled biomarkers as shown. For example, onco/tumor suppressor gene labeling contains 3 antibodies labeled with the same fluorochrome (KRASG12D, KRASG12V, P53mut; red channel); additional pancreatic cancer markers (EGFR, MUC1, and $\alpha F G-$ $\mathrm{P} 4 \mathrm{OH}$ ) are shown in the blue channel. Note the high signal-to-noise ratio of labeling individual EV as shown in the dashed lines (e.g. 1, 2 or 3). B) In case of positivity, any of the channels can be sub-speciated where each antibody contains a separate

A. Initial screen for pooled biomarkers
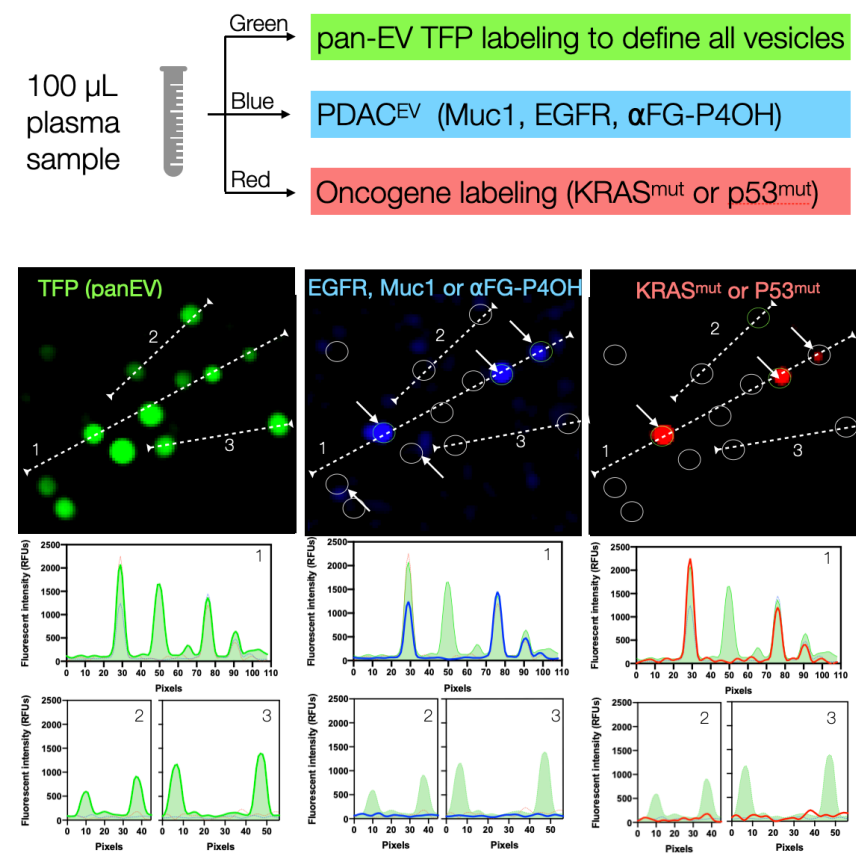

fluorochrome as shown.
B. Speciation if positive
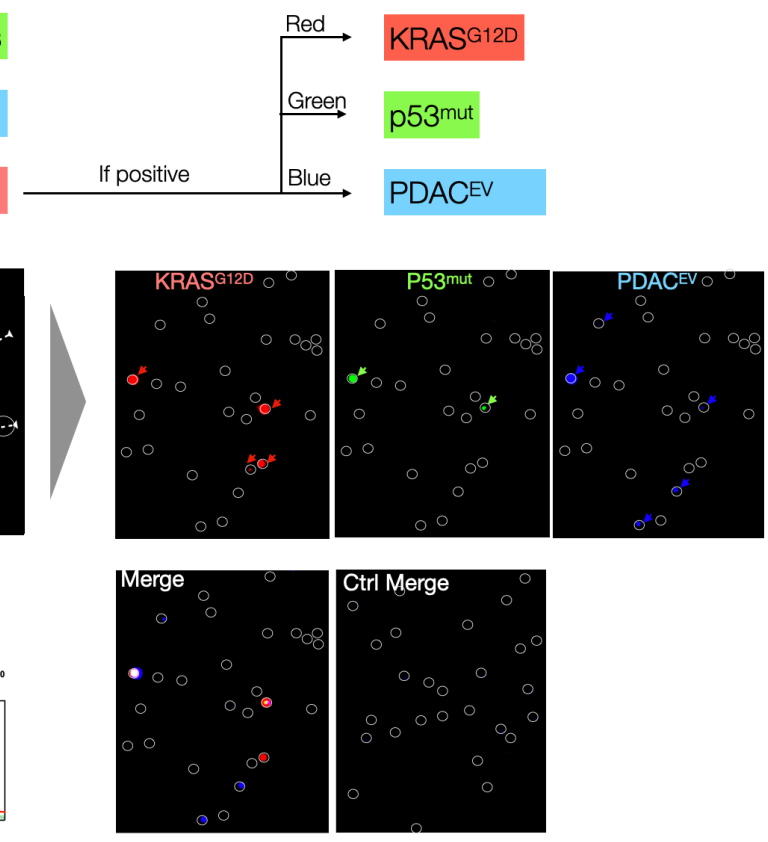
medRxiv preprint doi: https://doi.org/10.1101/2021.09.26.21263660; this version posted September 27, 2021. The copyright holder for this preprint (which was not certified by peer review) is the author/funder, who has granted medRxiv a license to display the preprint in perpetuity.

All rights reserved. No reuse allowed without permission.

Fig. 3: sEVA analysis across multiple PDAC cell line derived EV. A) Summary graph of the \% EV that stain for i) KRASmut or P53mut (red) ii) EGFR, MUC1, or $\alpha F G-P 4 O H$, (blue), iii) at least one of each of the former two markers panels (purple) or iv) no marker (grey). The sum of EV was determined by pan-TFP labeling. Each column represents a different cell line or PDX line (see Table 1 for characteristics of parental cells). B) Data plotted in Venn diagrams to show EV distribution across cell lines. Note the often large fraction of EV negative for any marker.

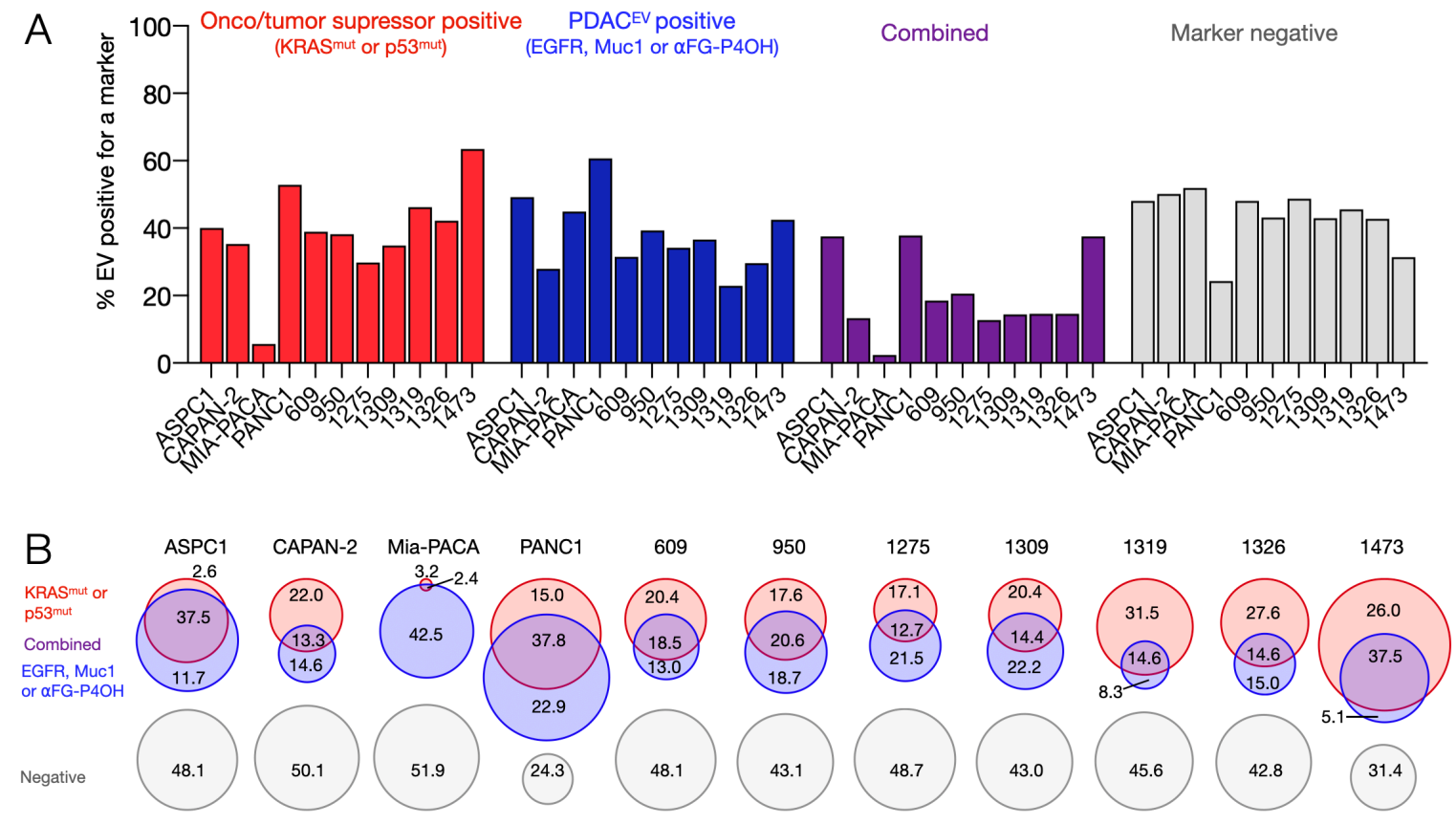


medRxiv preprint doi: https://doi.org/10.1101/2021.09.26.21263660; this version posted September 27, 2021. The copyright holder for this preprint (which was not certified by peer review) is the author/funder, who has granted medRxiv a license to display the preprint in perpetuity.

All rights reserved. No reuse allowed without permission.

Fig. 4: Clonal EV analysis. A) A serial dilution was performed to obtain single cell isolates from bulk cultures of PANC-1and AsPC-1 cells. EV were then collected from the media of the resulting clonal expansion culture and compared to EVs from the parent cell lines. B) The clone-derived EV were analyzed for expression of KRASG12D and MUC1. Each box represents $1 \%$ of total EV staining for either marker alone or dualpositive for both (purple) C) Different PANC-1 clones appeared similar to each other and the parental line. Conversely, AsPC-1 clones showed variable expression of KRASG12D and MUC1 in EV.
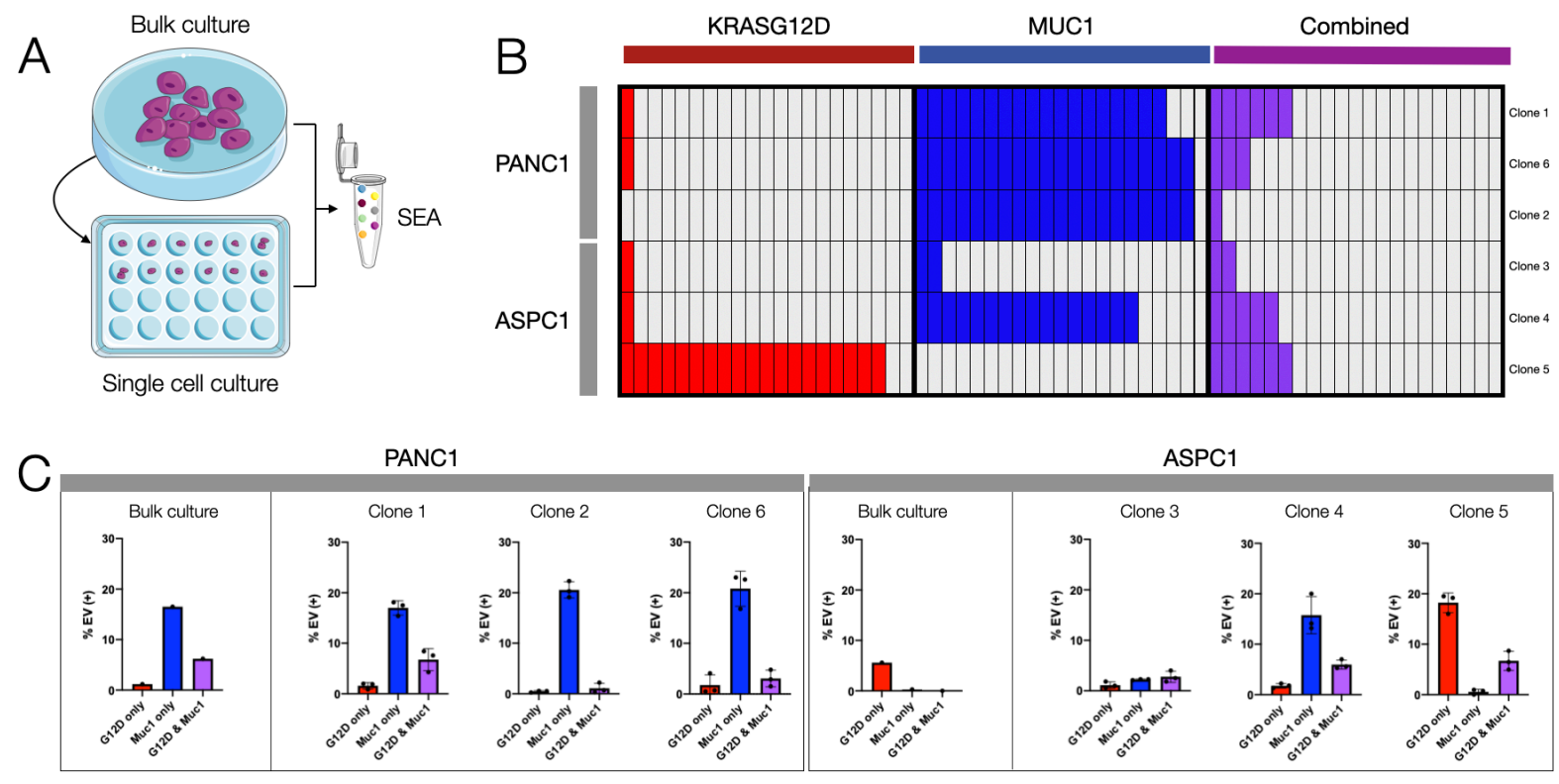
medRxiv preprint doi: https://doi.org/10.1101/2021.09.26.21263660; this version posted September 27, 2021. The copyright holder for this preprint (which was not certified by peer review) is the author/funder, who has granted medRxiv a license to display the preprint in perpetuity.

Fig. 5: EV based KRASG12D detection in clinical plasma sample. A) Representative images of a stage 4 PDAC, demonstrating superb colocalization of KRASG12D staining with TFP-labeled EV (green). Note that the bulk EV analysis of this sample failed to detect KRASmut B) Larger field of view of the same plasma sample. In this image, the TFP-ROI mask of all labeled EV is depicted by gray outlines while the KRASG12D staining is shown in red. Of $1618 \mathrm{EV}$ imaged (only a fraction is shown for better visibility), $1.24 \%$ were positive for KRASG12D. C) Group analysis of EV. The upper graphs show quantitative analysis of late stage PDAC samples $(n=4)$ against controls $(n=5)$. Note the high levels of EV positivity for KRASmut/P53mut as well as other PDAC biomarkers. The lower graphs show the correlation of EV positivity for KRASmut/P53mut against the known mutational status derived from sequencing of surgical tumor samples $(n=24$ samples). Note the excellent correlation between EV analysis and NGS results. See text for detail.

A

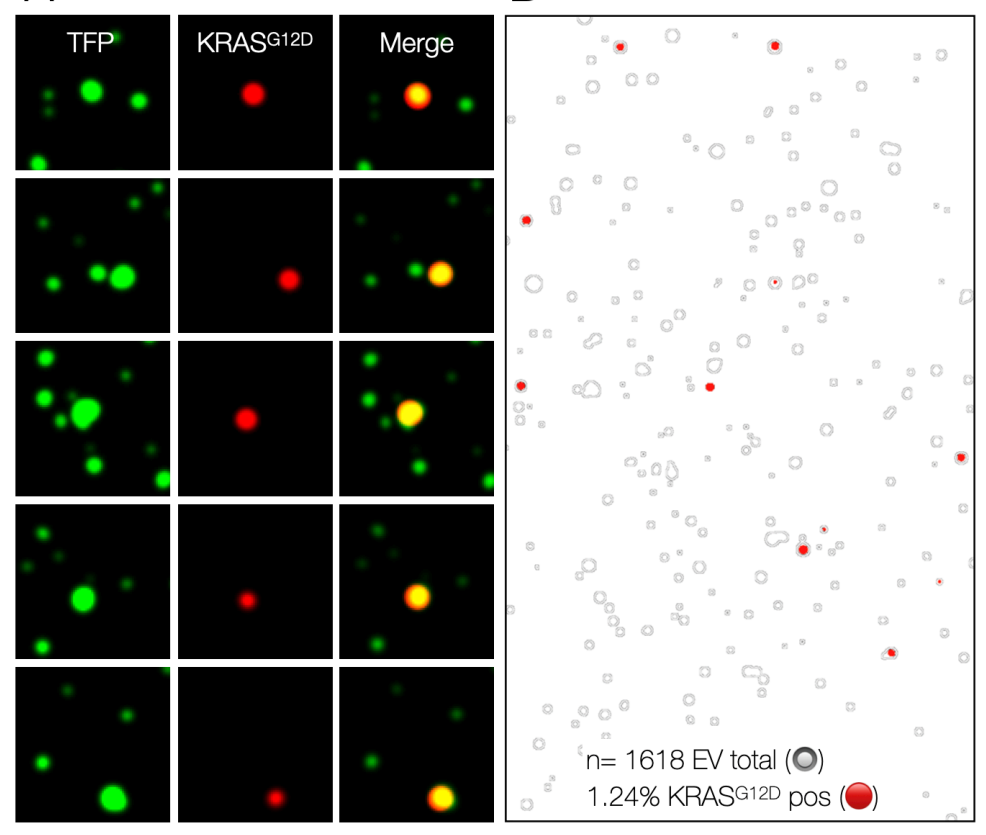

C
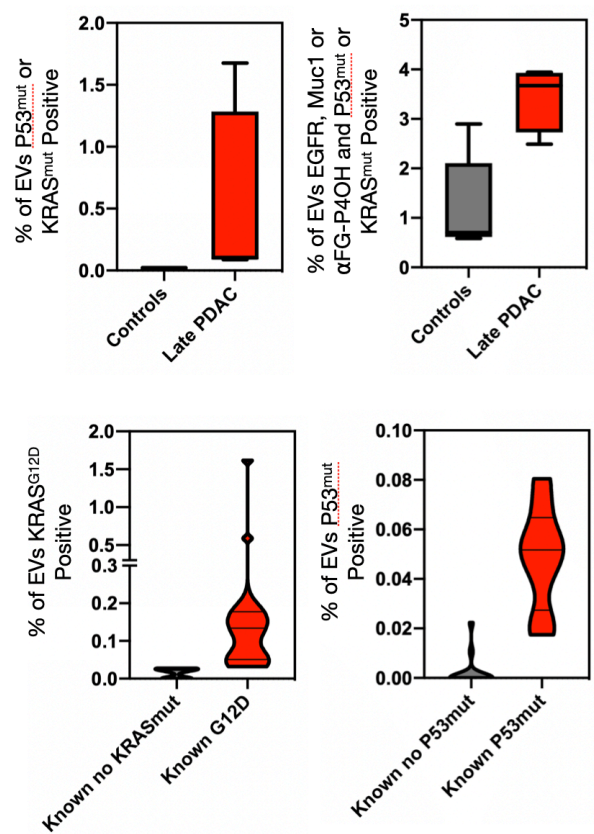
medRxiv preprint doi: https://doi.org/10.1101/2021.09.26.21263660; this version posted September 27, 2021. The copyright holder for this preprint (which was not certified by peer review) is the author/funder, who has granted medRxiv a license to display the preprint in perpetuity.

All rights reserved. No reuse allowed without permission.

Fig. 6: sEVA of clinical stage 1 PDAC cases. Analysis of KRASmut and P53mut in stage 1 PDAC plasma samples $(n=16)$ and in controls $(n=5)$. Note that virtually all stage 1 PDAC plasma samples had EV positive for either P53mut or KRASmut but only one sample contained double positive EV. Twelve of the 16 samples had dually positive EV that stained for either KRASmut/P53mut and EGFR/MUC1/ $\alpha$ FG-P4OH ("PDACEV"). The bottom graph shows the fraction of KRASmut or P53mut positive EV in plasma samples
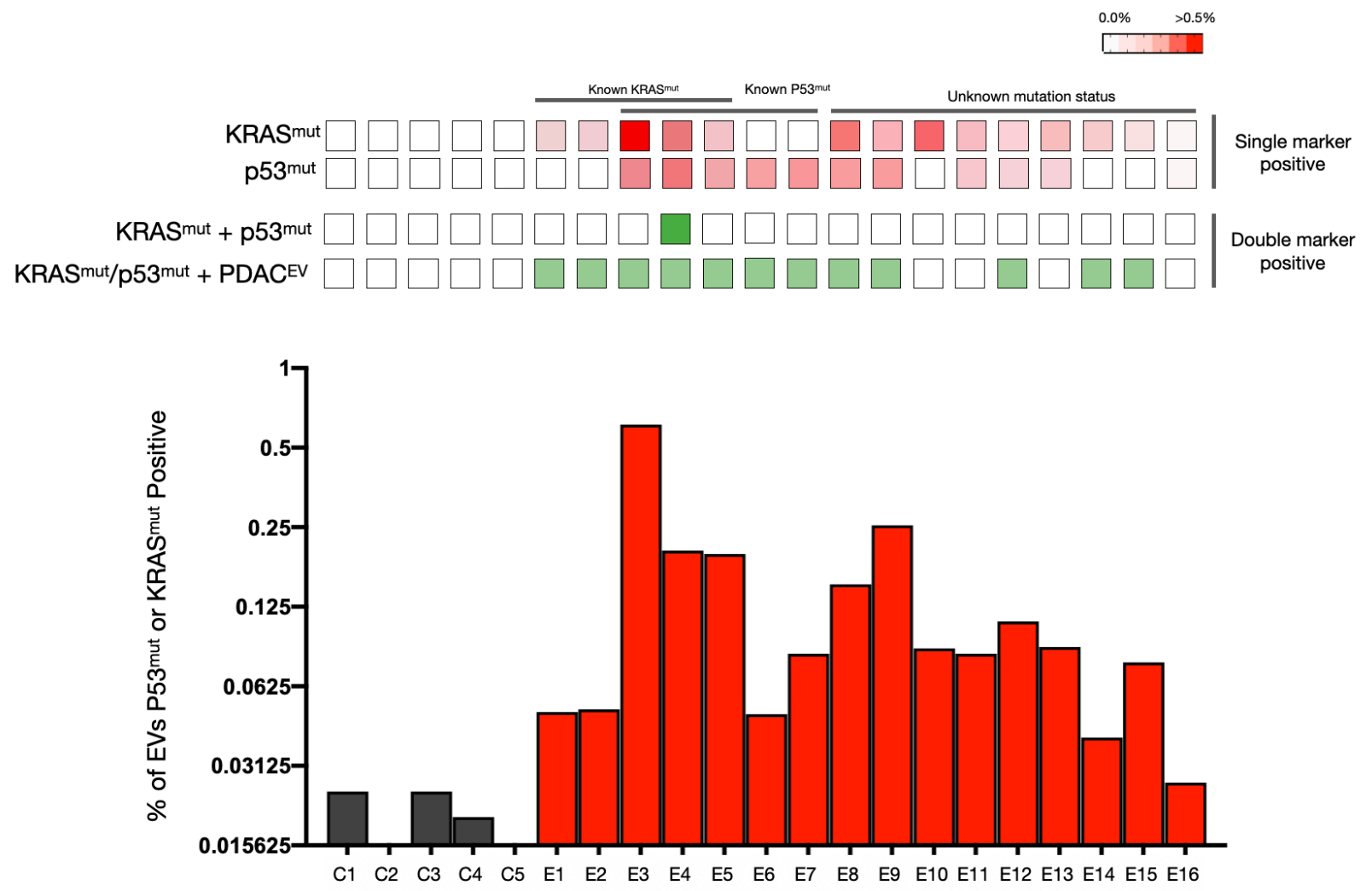
medRxiv preprint doi: https://doi.org/10.1101/2021.09.26.21263660; this version posted September 27, 2021. The copyright holder for this preprint (which was not certified by peer review) is the author/funder, who has granted medRxiv a license to display the preprint in perpetuity.

All rights reserved. No reuse allowed without permission.

Fig. 7: Modeling of PDAC cancer detection using plasma sEVA. A) A model of tumor-EV production, distribution and elimination(56) was combined with additional measurements of EV shed rates and the newly measured percent of EV positive for tumor-specific markers to $B$ ) simulate current detection limits of PDAC tumors across a population of variable tEV shed rates and with variable percent coverage of tumormarkers on the shed tEV. With the current set of markers shown in Fig. 6, $70 \%$ of PDAC are estimated to become detectable at a tumor volume of $0.1 \mathrm{~cm}^{3}$. With fadditional robust markers, this detection level could approach $97 \%$.
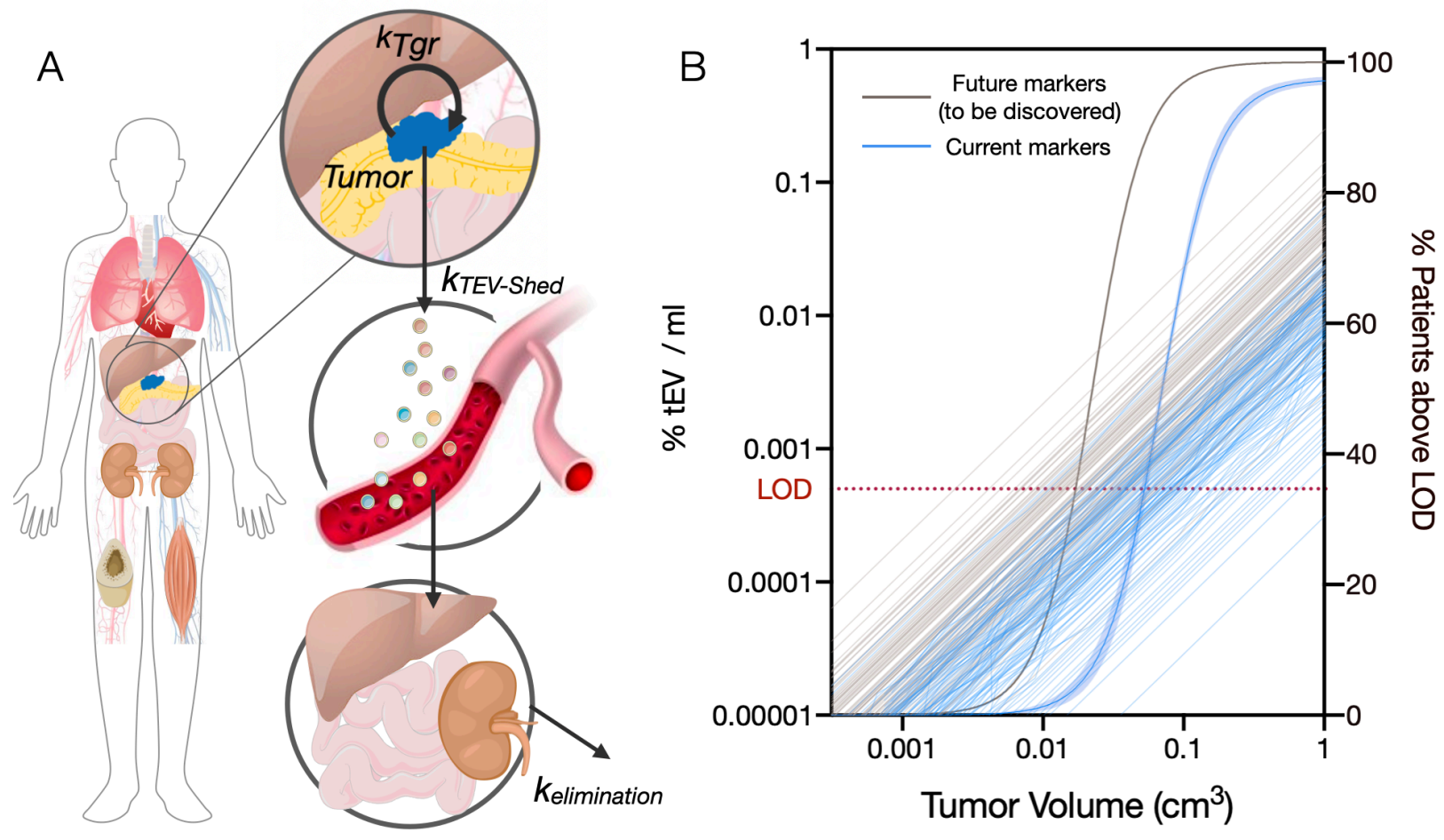
Table 1: Characteristics of PDAC cell lines used in study EV were obtained from a total of 11 cell lines and used for single EV analysis. The commercially available cells were from ATCC and have been described(42). The PDX cell lines were created at MGH and have partially been described $(9,43)$.

\begin{tabular}{|l|l|l|l|l|l|l|l|}
\hline Cell line & Source & Site & KRAS & P53 & MUC1 & EGFR & Comment \\
\hline AsPC-1 & ATCC & Ascites & G12D & Mut & + & ++++ & CRL-1682 \\
\hline Capan-2 & ATCC & Primary & G12V & WT & +++ & ++++ & HTB80 \\
\hline MIA PaCa-2 & ATCC & Primary & G12C & Mut & + & ++++ & CRL-1420 \\
\hline PANC-1 & ATCC & Primary & G12D & Mut & +++ & ++++ & CRL-1469 \\
\hline 609 & MGH & Primary & G12D & Mut & +++ & ++ & MGH PDX \\
\hline 950 & MGH & Primary & G12V & Mut & ++++ & $(-)$ & MGH PDX \\
\hline 1275 & MGH & Primary & G12V & Mut & ++ & + & MGH PDX \\
\hline 1309 & MGH & Primary & G12D & Mut & +++ & ++ & MGH PDX \\
\hline 1319 & MGH & Primary & G12D & Mut & +++ & ++++ & MGH PDX \\
\hline 1326 & MGH & Primary & G12D & Mut & ++ & + & MGH PDX \\
\hline 1473 & MGH & Primary & G12V & WT & ++ & ++ & MGH PDX \\
\hline
\end{tabular}


Table 2: Frequency of biomarker positive EV compared to parental cells Cancer biomarkers are less common in EV when compared to parental cells. For example, in AsPC- 1 cells only $37 \%$ of EV express mutant KRAS. PDAC EV refers to EV positive for EGFR, MUC1, and/or $\alpha$ FG-P4OH.

\begin{tabular}{|l|l|l|l|l|}
\hline Cell line & KRASmut & P53mut & PDAC EV & No Marker \\
\hline AsPC-1 & 0.368 & 0.046 & 0.492 & 0.481 \\
\hline Capan-2 & 0.352 & 0.002 & 0.279 & 0.501 \\
\hline MIA PaCa-2 & 0.036 & 0.022 & 0.449 & 0.519 \\
\hline PANC-1 & 0.341 & 0.39 & 0.607 & 0.243 \\
\hline 609 & 0.349 & 0.133 & 0.315 & 0.481 \\
\hline 950 & 0.363 & 0.047 & 0.393 & 0.431 \\
\hline 1275 & 0.282 & 0.03 & 0.342 & 0.487 \\
\hline 1309 & 0.212 & 0.217 & 0.366 & 0.43 \\
\hline 1319 & 0.398 & 0.157 & 0.229 & 0.456 \\
\hline 1326 & 0.406 & 0.055 & 0.296 & 0.428 \\
\hline 1473 & 0.635 & 0.005 & 0.425 & 0.314 \\
\hline
\end{tabular}


Table 3: Characteristics of patient samples

Plasma was obtained from 25 patients, including 16 patients with stage 1 PDAC, 4 patients with late stage PDAC and 5 healthy controls. sEVA was performed on $100 \mu \mathrm{L}$ of purified plasma. *ND = not determined. KRAS and P53 status was determined by sequencing of the primary tumor.

\begin{tabular}{|c|c|c|c|c|c|c|}
\hline Patient sample & Dx & Stage & TNM & Sex & KRAS & P53 \\
\hline E1 & Early PDAC & I & T1N0 & male & G12D & ND \\
\hline E2 & Early PDAC & I & T1N1 & male & G12D & WT \\
\hline E3 & Early PDAC & I & T1No & female & G12D & R213 Ter \\
\hline E4 & Early PDAC & 1 & T1N0 & male & G12D & Y220C \\
\hline E5 & Early PDAC & 1 & T2NO & female & G12R & Y163C \\
\hline E6 & Early PDAC & 1 & T2NO & male & Q61K & R196 Ter \\
\hline E7 & Early PDAC & 1 & T1N0 & female & Q61H & $\begin{array}{c}\text { R196H fs Ter 52; } \\
\text { N239S }\end{array}$ \\
\hline E8 & Early PDAC & 1 & T2NO & female & ND & ND \\
\hline E9 & Early PDAC & I & T1N0 & female & ND & ND \\
\hline E10 & Early PDAC & I & T1No & female & ND & ND \\
\hline E11 & Early PDAC & I & T1N0 & female & ND & ND \\
\hline E12 & Early PDAC & I & T2NO & female & ND & ND \\
\hline E13 & Early PDAC & 1 & T2NO & male & ND & ND \\
\hline E14 & Early PDAC & I & T1No & male & ND & ND \\
\hline E15 & Early PDAC & 1 & T1N0 & female & ND & ND \\
\hline E16 & Early PDAC & 1 & T1No & female & ND & ND \\
\hline L1 & Late PDAC & IV & T4NxM1 & male & WT & R213W \\
\hline L2 & Late PDAC & II b & T2N1 & female & G12R & $\mathrm{R} 273 \mathrm{H}$ \\
\hline L3 & Late PDAC & II b & T2N1 & male & G12C & G266 Ter \\
\hline L4 & Late PDAC & IV & T4N1M0 & male & G12D & R282W \\
\hline C1 & Healthy & - & - & male & - & - \\
\hline C2 & Healthy & - & - & male & - & - \\
\hline C3 & Healthy & - & - & female & - & - \\
\hline $\mathrm{C} 4$ & Healthy & - & - & female & - & - \\
\hline C5 & Healthy & - & - & female & - & - \\
\hline
\end{tabular}


Table 4: Affinity labels used for sEVA analysis

\begin{tabular}{|l|l|l|l|l|l|l|}
\hline Target & Reagent & Vendor & Catalog \# & Flurochrome & DOL & $\begin{array}{l}\text { Ex/Em } \\
\text { filters }\end{array}$ \\
\hline All EV (TFP) & TFP & $\begin{array}{l}\text { Thermo } \\
\text { Fisher }\end{array}$ & A37570 & AF488 & N/A & $472 / 520$ \\
\hline KRASG12D & $\begin{array}{l}\text { anti- } \\
\text { KRASG12D }\end{array}$ & Genetex & GTX635362 & AF594 & 3.4 & $562 / 593$ \\
\hline KRASG12V & $\begin{array}{l}\text { anti- } \\
\text { KRASG12V }\end{array}$ & CellSignaling & $\begin{array}{l}14412 B F \\
(\text { Special } \\
\text { order) }\end{array}$ & AF594 & 1.7 & $562 / 593$ \\
\hline P53mut & Anti-P53mut & Abcam & ab247264 & AF488 & 4 & $472 / 520$ \\
\hline P53mut & Anti-P53mut & Abcam & ab32049 & AF555 & 3.6 & $562 / 593$ \\
\hline MUC-1 & Anti-MUC-1 & Biolegend & 355602 & AF680 & 2.8 & $628 / 692$ \\
\hline EGFR & anti-EGFR & Abcam & Ab30 & AF680 & 3.1 & $628 / 692$ \\
\hline$\alpha$ FG-P4OH & $\begin{array}{l}\text { anti- } \alpha \text { FG- } \\
\text { P4OH }\end{array}$ & Diagnocine & KC600 & AF680 & 5.1 & $628 / 692$ \\
\hline & & & & & & \\
\hline
\end{tabular}


Table 5: Parameters for EV modeling.

\begin{tabular}{|c|c|c|c|c|c|}
\hline \multicolumn{6}{|c|}{ Previously Described Model Parameterization } \\
\hline Parameter & Description & Species/Cancer & Estimate & $\begin{array}{c}\text { (CV\%) / }[95 \% \\
\text { CI] }\end{array}$ & Notes \\
\hline $\mathbf{V}_{\mathrm{d}-\mathrm{m}}$ & Volume of distribution (ml) & Mouse & 1.53 & Fix & $\begin{array}{c}\text { Shah \& Betts (2012) scaled to } 25 \mathrm{~g} \\
\text { mouse }\end{array}$ \\
\hline $\mathbf{V}_{\mathrm{d}-\mathrm{h}}$ & Volume of distribution (ml) & Human & 6,004 & Fix & $\begin{array}{c}\text { Shah \& Betts (2012) scaled to } 75 \mathrm{~kg} \\
\text { male }\end{array}$ \\
\hline RenalExc & Renal Elimination (day-1) & Mouse/Human & $\begin{array}{c}1.932 \times \\
10^{-2}\end{array}$ & $(29.31)$ & Model Estimate \\
\hline Fecalexc & Fecal Elimination (day ${ }^{-1}$ ) & Mouse/Human & $\begin{array}{c}1.031 \times \\
10^{-2}\end{array}$ & $(16.00)$ & Model Estimate \\
\hline RES uptake $_{\text {un }}$ & Hepatic Uptake (day-1) & Mouse/Human & 0.3055 & $(5.516)$ & Model Estimate \\
\hline vascKon & Vasculature $K_{\text {on }}\left(\right.$ day-1$\left.^{-1}\right)$ & Mouse/Human & 0.6397 & $(5.418)$ & Model Estimate \\
\hline vascKoff & Vasculature $K_{\text {off }}$ (day-1) & Mouse/Human & $\begin{array}{l}2.336 \times \\
10^{-2}\end{array}$ & $(18.18)$ & Model Estimate \\
\hline HepEli & $\begin{array}{l}\text { Hepatic Elimination } \\
\left(\text { day }^{-1}\right)\end{array}$ & Mouse/Human & $\begin{array}{c}6.264 \times \\
10^{-3}\end{array}$ & $(7.961)$ & Model Estimate \\
\hline $\mathbf{k}_{\text {Tgr }}$ & $\begin{array}{l}\text { Tumor Growth Rate } \\
\left(\text { day }^{-1}\right)\end{array}$ & & $\begin{array}{c}1.424 x \\
10^{-2}\end{array}$ & $\begin{array}{c}{[0.0072-} \\
0.0229]\end{array}$ & Gompertz Fit \\
\hline Tumormax & Max Tumor Volume (ml) & $\begin{array}{l}\text { KPC Pancreatic } \\
\text { Sharma et al } \\
\text { (2017) }\end{array}$ & 477.0 & {$[401.0-673.8]$} & Gompertz Fit \\
\hline $\mathbf{K}_{\mathrm{tEV}-\mathrm{SHED}}$ & $\begin{array}{l}\text { Shed Rate of Tumor EVs } \\
\left(\text { day }^{-1}\right)\end{array}$ & & 0.2208 & $(5.399)$ & Model Estimate \\
\hline $\mathbf{k}_{\mathrm{Tgr}}$ & $\begin{array}{l}\text { Tumor Growth Rate } \\
\text { (day-1) }\end{array}$ & & 0.1098 & - & Gompertz Fit \\
\hline Tumormax & Max Tumor Volume (ml) & $\begin{array}{l}\text { KIC Pancreatic } \\
\text { Sharma et al } \\
\text { (2017) }\end{array}$ & 1953 & {$[1,629-2,279]$} & Gompertz Fit \\
\hline $\mathbf{K}_{\text {tEV-SHED }}$ & $\begin{array}{l}\text { Shed Rate of Tumor EVs } \\
\left(\text { day }^{-1}\right)\end{array}$ & & $\begin{array}{c}5.428 \times \\
10^{-2}\end{array}$ & $(18.12)$ & Model Estimate \\
\hline \multicolumn{6}{|c|}{ Parameterization for Model Simulations } \\
\hline Parameter & Description & Species/Cancer & Estimate & SD & Notes \\
\hline $\mathbf{K}_{\mathrm{tEV}-\mathrm{SHED}}$ & $\begin{array}{l}\text { Shed Rate of Tumor EVs } \\
\left(\text { day }^{-1}\right)\end{array}$ & Human PDX & 0.0660 & 0.0627 & Experimentally derived \\
\hline $\mathbf{K}_{\mathrm{tEV}-\mathrm{SHED}}$ & $\begin{array}{l}\text { Shed Rate of Tumor EVs } \\
\left(\text { day }^{-1}\right)\end{array}$ & Human & 0.0477 & 0.0465 & Simulated trial \\
\hline Marker+ & $\begin{array}{l}\% \text { tEV positive for a tested } \\
\text { marker }\end{array}$ & Human PDX & $37.1 \%$ & $15.65 \%$ & Experimentally derived \\
\hline Marker+ & $\begin{array}{l}\% \text { tEV positive for a tested } \\
\text { marker }\end{array}$ & Human & $33.7 \%$ & $14.44 \%$ & Simulated trial \\
\hline
\end{tabular}




\section{Supplemental information}

\section{Single EV analysis (sEVA) of mutated proteins allows detection of stage 1 pancreatic cancer}

Scott Ferguson ${ }^{1}$, Katherine S. Yang1, Piotr Zelga 2, Andrew S. Liss ${ }^{2}$, Jonathan

Carlson 1 , Carlos Fernandez del Castillo1,2, Ralph Weissleder1,3,*

${ }^{1}$ Center for Systems Biology, Massachusetts General Hospital, 185 Cambridge St, CPZN 5206, Boston, MA 02114,

2 Department of Surgery, Massachusetts General Hospital, 32 Fruit St, Boston, MA 02114,

3 Department of Systems Biology, Harvard Medical School, 200 Longwood Ave, Boston, MA 02115

${ }^{*}$ R. Weissleder, MD, PhD

Center for Systems Biology

Massachusetts General Hospital

185 Cambridge St, CPZN 5206

Boston, MA, 02114

617-726-8226

rweissleder@mgh.harvard.edu 
medRxiv preprint doi: https://doi.org/10.1101/2021.09.26.21263660; this version posted September 27, 2021. The copyright holder for this preprint (which was not certified by peer review) is the author/funder, who has granted medRxiv a license to display the preprint in perpetuity. All rights reserved. No reuse allowed without permission.

Fig. S1: Labeling and purification steps in sEVA. Prior to concentrating and purifying EV, a number of steps were necessary to pre-purify samples. First, culture media was spun at $500 \mathrm{~g}$ for 5 minutes to remove cells and large cellular debris and the supernatant was then spun at $2000 \mathrm{~g}$ for 10 minutes for removal of apoptotic blebs and other micronsized cellular material. The supernatant was then ultracentrifuged using the Beckman Coulter Optima-L-90K ultracentrifuge with the SW 32 Ti rotor, spinning at $24200 \mathrm{rpm}$ for 70 minutes. 1) EV obtained from plasma or cell culture media are purified and concentrated using a qEV singlesize exclusion column (IZON) since ultracentrifugation can co-pellet non-vesicle material. Following $1 \mathrm{ml}$ void volume, $650 \mu \mathrm{l}$ was collected and used for subsequent labeling. 2) The entirety of EV were labeled with the amine reactive AF488-PEG-TFP dye to define all EV. Unreacted AF488 was removed by Zeba columns. 3) AF488-PEG-TFP labeled EV were co-labeled with fluorescent antibodies. Following labeling, unbound antibodies were removed with a second IZON column. 4) Labeled EV were pipetted onto hydrophobic glass sides and cover slipped. 5) EV were imaged and multicolor images were then analyzed as detailed in Fig S2.
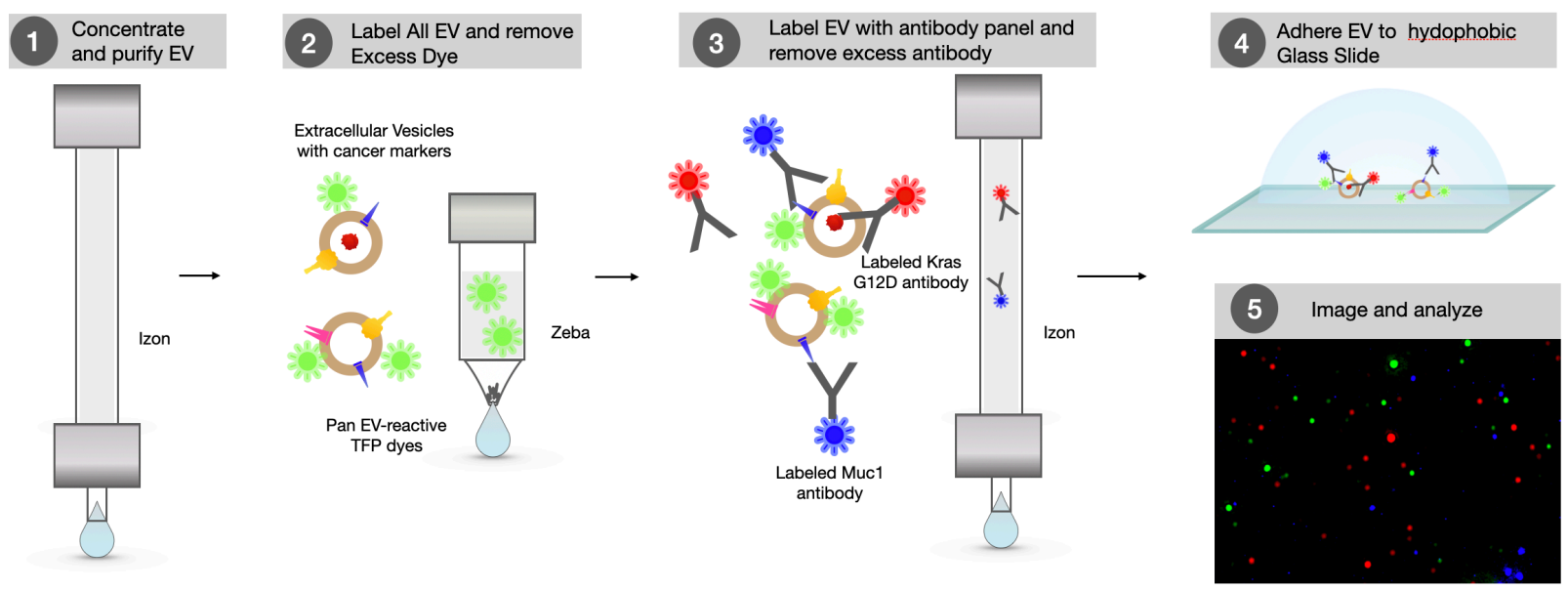
medRxiv preprint doi: https://doi.org/10.1101/2021.09.26.21263660; this version posted September 27, 2021. The copyright holder for this preprint (which was not certified by peer review) is the author/funder, who has granted medRxiv a license to display the preprint in perpetuity.

All rights reserved. No reuse allowed without permission.

Fig. S2: Flowchart of image analysis. The pipeline shows the image acquisition and analysis parameters to obtain analyzable and reproducible data. Note that following confirmation of high-quality images, all data points were obtained by automated analysis and not by "visual inspection". Marker signal intensity was measured only on regions demarcated by TFP-labeling to avoid non-specific signals not localized to EV. These measurements were analyzed in GraphPad Prism v8 to determine optimal threshold values between control samples and positive samples by maximizing the likelihood ratio of the receiver operator characteristic curve. Logic statements within Microsoft Excel were used to determine percent positive EVs for each sample, as well as co-positive EVs.

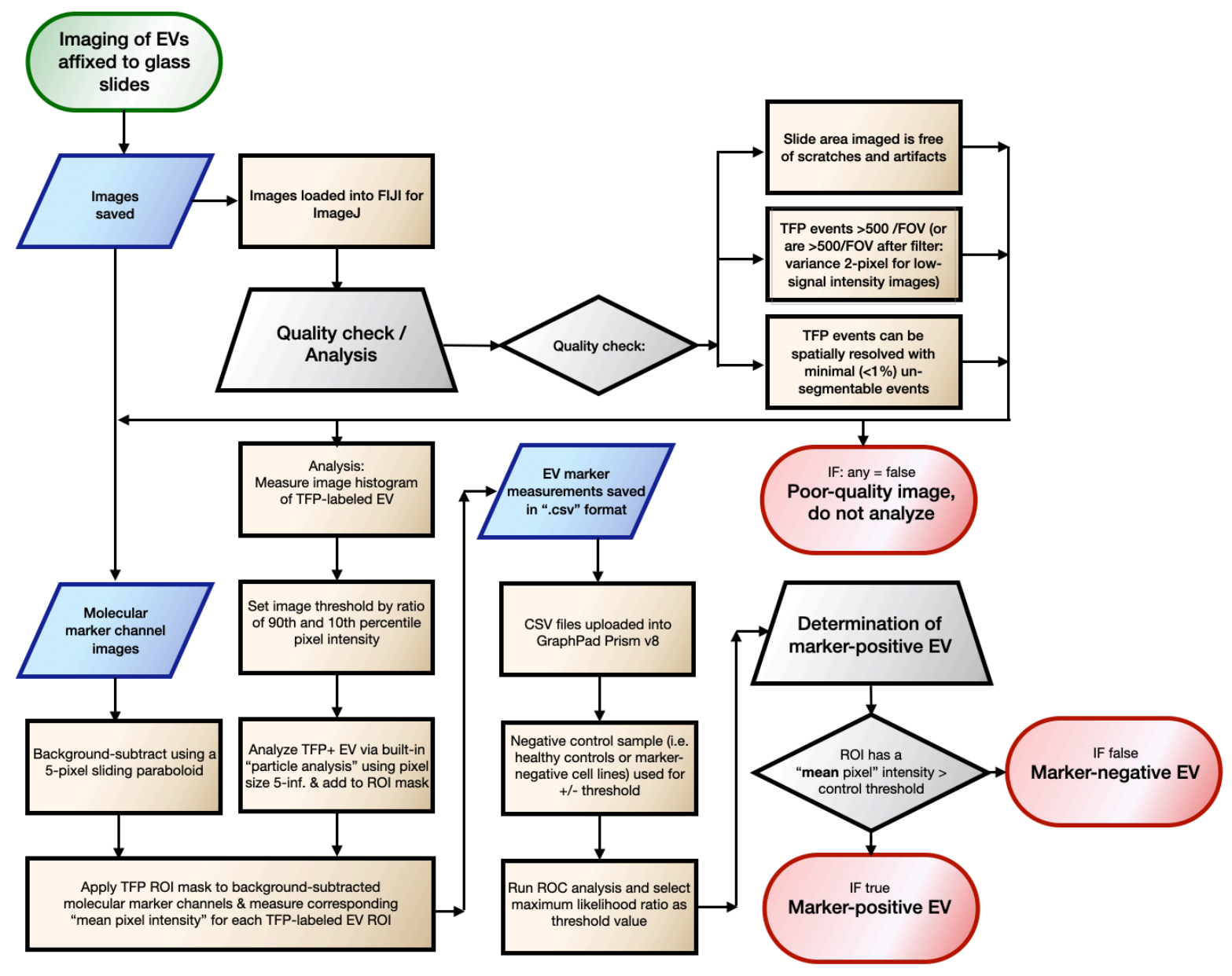


medRxiv preprint doi: https://doi.org/10.1101/2021.09.26.21263660; this version posted September 27, 2021. The copyright holder for this preprint (which was not certified by peer review) is the author/funder, who has granted medRxiv a license to display the preprint in perpetuity.

All rights reserved. No reuse allowed without permission.

Fig. S3: Analysis of potential spectral crosstalk. A) Detection of EVs labeled with different TFP-fluorophores. EV derived from PANC1 cells were labeled with different fluorochrome (AF350, AF488, AF647) tagged TFP and then imaged by microscopy either as purified or mixed populations. B) Cross-section analysis of mixed TFP population. Note the high signal-to-noise ratio of individually labeled vesicles and specificity of each label as evidenced by the absence of signal overlap between the discretely labeled EV.

A
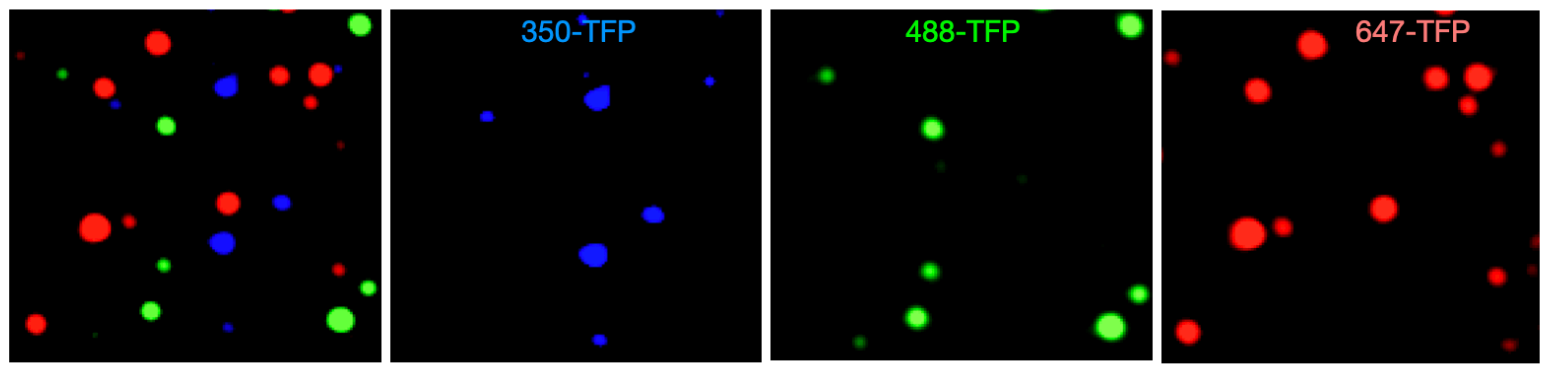

B

TFP-Labeled EV can be readily resolved without spurious signal

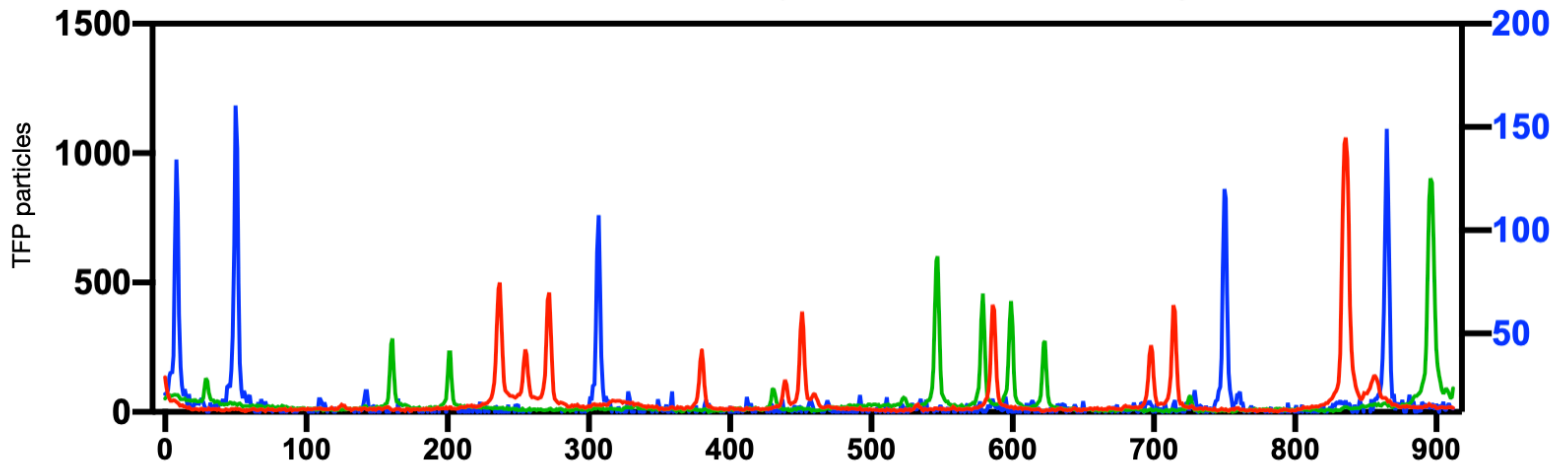


medRxiv preprint doi: https://doi.org/10.1101/2021.09.26.21263660; this version posted September 27, 2021. The copyright holder for this preprint (which was not certified by peer review) is the author/funder, who has granted medRxiv a license to display the preprint in perpetuity. All rights reserved. No reuse allowed without permission.

Fig. S4 Model Equations: Equations 1 - 5 describe tEV distribution and elimination in mass units where: vasckon is the first order rate constant describing association of tEV to the vascular walls, vasc $c_{\text {koff }}$ is the first order rate constant describing dissociation of tEV from the vascular walls back into circulation, RenalEXC and Fecal EXC are the first order rate constants of tEV eliminated into urine and feces, respectively, $R E S_{\text {uptake }}$ is the first order rate constant of hepatic uptake, and $\mathrm{Hep}_{E l i}$ is the first order rate constant of tEV eliminated in the liver (days $\left.{ }^{-1}\right)$.

Equation 6 describes the tumor growth dynamics and production of tEV. $k_{T g r}$ is the first order growth rate of the tumor (days ${ }^{-1}$ ) and Tumormax is the maximum tumor volume $\left(\mathrm{mm}^{3}\right)$. Under the case where a tumor is present, tEV input from equation 6 is modeled in equation 1 by the first order tumor-EV shed rate: $k_{t E V S H E D}\left(\right.$ days $\left.^{-1}\right)$.

Eq. 1, Tumor EVs in circulation:

$\frac{d \mathrm{tEV}}{d t}=-\left(\right.$ vasc $\left._{\text {Kon }} \times \mathrm{tEV}\right)-\left(\right.$ Renal $\left._{\text {EXC }} \times \mathrm{tEV}\right)-\left(\right.$ Fecal $\left._{\text {EXC }} \times \mathrm{tEV}\right)-\left(\right.$ RES $\left._{\text {uptake }} \times \mathrm{tEV}\right)+\left(\right.$ vasc $\left._{\text {Koff }} \times \mathrm{VASC}\right)+\left(\mathrm{TUMOR} \times k t E V_{\text {SHED }}\right)$

Eq. 2. Tumor EVs bound to vasculature:

$\frac{d \mathrm{VASC}}{d t}=\left(\operatorname{vasc}_{K o n} \times \mathrm{tEV}\right)-\left(\operatorname{vasc}_{K o f f} \times \mathrm{VASC}\right)$

Eq. 3, Tumor EVs cleared by the liver:

$\frac{d \text { LIVER }}{d t}=\left(\mathrm{tEV} \times R E S_{\text {uptake }}\right)-\left(\right.$ LIVER $\left.\times H e p_{E l i}\right)$

Eq. 4, Tumor EVs cleared renally:

$\frac{d \mathrm{URINE}}{d t}=\left(\mathrm{tEV} \times \operatorname{Renal}_{E X C}\right)$

Eq. 5, Tumor EVs cleared fecally:

$\frac{d \mathrm{FECES}}{d t}=\left(\mathrm{tEV} \times\right.$ Fecal $\left._{E X C}\right)$ 
medRxiv preprint doi: https://doi.org/10.1101/2021.09.26.21263660; this version posted September 27, 2021. The copyright holder for this preprint (which was not certified by peer review) is the author/funder, who has granted medRxiv a license to display the preprint in perpetuity.

All rights reserved. No reuse allowed without permission.

\section{Eq. 6. Tumor volume:}

$$
\frac{d \text { TUMOR }}{d t}=k_{T g r} \times \log \left(\frac{\text { Tumor }_{\text {Max }}}{\text { TUMOR }}\right) \times \text { TUMOR }
$$

